\title{
The Dutch crush on compensating crime victims
}

\author{
IVO GIESEN, FRANÇOIS KRISTEN AND RENÉE KOOL
}

\section{Introduction}

In this chapter we set out to supply the reader with an integrated account of the law in the Netherlands as regards the interaction and interrelationship between tort law and criminal law, most notably criminal procedure. We analyse the different forms and modes of interaction, dependence and influence between (the rules on) tort and crime, focusing on the position of the victim of a crime of some sort who has suffered some form of harm. In particular, we pay attention to how and by which route, criminal law or private law, victims of crime can be compensated.

The chapter starts by mapping the three key components of the interaction between tort and crime (in Section 2) and continues by analysing each of these three components in more detail in Sections 3 to 5. For each of those three sections we will answer three basic questions: where, how and why tort and crime have interacted. After a brief comment in Section 6 on why tort and crime developed as it has, Section 7 rounds off the chapter with a short conclusion. As will become apparent, Dutch law seeks to handle cases efficiently while still observing coherence of criminal law and private law and maintaining the unity of the legal system.

\section{Three key components of the crime and tort relationship}

If one were to take a helicopter view over the daily activities of the Dutch legal system, one would see three major component parts in the interaction between crime and tort in the Netherlands:

(1) Crimes are torts and torts may be crimes;

(2) A criminal court is equivalent to a civil court when it comes to dealing with the victim's tort claim; and 
(3) Criminal conviction is strong evidence for a later related tort claim filed in a civil court after the criminal case is decided by the criminal court.

These three components will be briefly discussed and thus provide a brief introduction to the Dutch system, before they are explored in more detail.

First, under Dutch law, contrary to some systems, particularly in the common law, an act prohibited as unlawful by the criminal law, is also an unlawful act for the purposes of Dutch tort law. ${ }^{1}$ Article 6:162 BW (Burgerlijk Wetboek, the Civil Code) expresses this in paragraph 2 by defining an unlawful act as, amongst other things, 'an act or omission in violation of a duty imposed by written law.' ${ }^{2}$ Since all criminal acts are contraventions of written law in the Dutch Criminal Code (Wetboek van Strafrecht, $\mathrm{Sr}^{3}$ ) or other (specific) acts with criminal offences, each criminal act is also a violation of a duty imposed by law.

To a certain extent this is also true in reverse: a tort can in criminal law amount to unlawful behaviour that meets the requirement of 'unlawfulness', one of the conditions for criminal liability. When the other elements of the criminal offence are also met, there is a crime and thus the tort is then a crime. Since criminal offences often require more than 'unlawfulness' (or an autonomous interpretation is given to the idea of 'unlawfulness' in criminal law), in most cases a tort does not coincide with crime and therefore the tort cannot be classified as a crime.

Second, consistent with the first general rule that each crime constitutes a tort in private law, Dutch law considers it efficient to let the criminal court that handles the criminal case also decide on the parallel tort claim if the victim of the crime so desires. If that court rules that a criminal act has taken place, it can immediately rule also on the tort law aspects of the behaviour in question, functioning, as it were, as a civil court and applying rules of tort law. This is the so-called vordering benadeelde partij, the 'claim by an injured party', as regulated by Article 51f Dutch Code of Criminal Procedure (Wetboek van Strafvordering, Sv) in conjunction with Article 6:162 BW. However, a precondition for this efficient approach to

1 The other elements that are always needed to constitute a tort (an onrechtmatige daad), in the private law sense, still need to be established as well. Think of damage(s), causation, imputability and relativity.

2 See Section 3.B for a complete quotation of Art. 6:162 BW.

3 This common abbreviation lacks a reference to 'Wetboek' like the common abbreviation for the civil code, BW. The same applies for the Code of Criminal Procedure, the 'Wetboek van Strafvordering', Sv. The only reason for this usage we can think of is the wish to be so brief as possible. 
the tort claim in the criminal trial is that the discussion of the claim by the criminal court does not cause a disproportionate burden and hinder the criminal trial. An example of an undue burden would be where tort liability, or quantum, are complex. In such cases, the criminal court declares the tort claim inadmissible, leaving it to the plaintiff to file a civil suit. In practice, anything 'out of the ordinary', anything that cannot be dealt with simply, is seen as a complicating factor so only the run of the mill tort claims are dealt with through the vordering benadeelde partij. ${ }^{4}$

Third, once a criminal court has decided in a criminal trial at which the defendant was present that a certain act is, in law, a criminal act, this ruling serves as compelling (but not conclusive) evidence in any ensuing civil proceedings. This follows from the Dutch Code of Civil Procedure (Wetboek van Burgerlijke Rechtsvordering hereafter, Rv), which states in Article 161 that a final criminal conviction is compelling evidence of the criminal act in civil proceedings. However, this compelling evidence can be challenged by counter-evidence produced by the convicted person in the civil proceedings. If so, the compelling evidence is not conclusive (see Article 151(2) Rv). In practice this will hardly ever be forthcoming. But there is much more to the evidentiary relationship between tort and crime, as will become clear hereafter.

Of course, our division into three component parts begs the question why these defining components are in fact so defining. These three factors touch upon the main characteristics of the Dutch law on tort and crime, they are not just technical details in the law. More importantly, the most basic starting point in the Dutch legal system is that an act that is considered so objectionable to be declared 'forbidden' by the legislature, after having gone through a democratic parliamentary process, and thus entailing the chance of criminal prosecution and sanctioning, should also be considered a (private law) tort. If not, one part of the law would permit that which another part would not. Hence, the unity of the legal system as well as its internal coherence is at stake. In this context we address with 'unity of the legal system' the way Dutch law as a system deals with illegal behaviour and how to provide for redress. We use 'coherence' to refer to the mutual connection of principles, concepts, norms and rules of criminal law and tort law in terms of contents, cohesion, consistency, scope and structure within their own area of the law as well as in the relationship between tort and crime. Both logic as well as the 'unity of the system' and

${ }^{4}$ See Section 4.C and M. ten Brinke, S. Habets and C. Noordam, 'Het nieuwe ontvankelijkheidscriterium in de praktijk' (2014) Trema 83. 
'coherence' of the system of law seem to require this line of reasoning. Interestingly, Dutch lawyers seem to accept this unity and coherence without discussion or debate. This might suggest that the homogeneity of the legal system so reached is but a side-effect of a practice that has developed without any (generally accepted) concept of coherence in mind.

That same, rather 'unphilosophical' and practical approach is probably also behind the second key component: the choice to deal with two (in essence, distinct) cases at once, within one criminal procedure. If the criminal court is dealing with morally blameworthy, criminal acts, let it also decide on the private law consequences of those same acts. That is efficient. So too the third component: why not use the conviction in a later civil court since it is based on evidence gathered and already judicially tested? The question answers itself, or at least that is what the Dutch seem to think. At the same time, there are in Dutch law no 'transfers' of tort to crime or vice versa. Both remain separate areas of law, with different institutions (criminal versus civil courts, professional groups etc.) and with their own rules, norms, principles, doctrine, jurisprudence and case law. We have already shown how the exception to the second key component itself proves this: where there are complex elements in the civil claim, a criminal court will declare the claim admissible and the claimant must seek the expertise of a (separate) civil court.

We will now turn to elaborate on these three components, and their links to further issues across Dutch law.

\section{Crime $=$ tort and tort $\approx$ crime}

\section{A. Introduction}

Criminal law and tort law both serve public interests. Both aim at controlling society by offering some form of redress to victims of behaviour which constitutes a crime and/or a tort and/or redress to society at large. To that end both offer the possibility of holding someone liable ${ }^{5}$ for a certain act, behaviour or situation, although the consequences of this

${ }^{5}$ In our contribution we use the terms 'liable' and 'liability' in the sense of the attachment of legal consequences to someone's conduct, which is the result of holding someone accountable. We define accountability in a procedural manner; it is the process aimed at a subsequent public assessment of a person's conduct in a given case in order to evaluate whether this conduct was required and/or justified by this person's responsibility which follows from (unwritten) law and moral and ethical standards, and once this evaluation is executed, to establish who can be held liable and to what extent. See I. Giesen and F. G. H. Kristen, 'Liability, Responsibility and Accountability: Crossing Borders' (2014) 
liability will differ between criminal law and tort law. Therefore, the substantive criminal law and tort law do have something in common. In this section we identify where tort and crime overlap and where they do not. To that end we compare the basic requirements of tort and crime: once we have established where tort and crime overlap (Section 3.B), we turn to assess how they do so (Section 3.C) before exploring why (Section 3.D).

\section{B. Where is the overlap (or the difference)?}

When an act or omission occurs which is considered to be reprehensible according to moral, social or other (policy) standards ${ }^{6}$ the Dutch legal order offers, basically, two forms of redress: criminal or civil liability. ${ }^{7}$ In both cases it is all about imputing the act (or the omission) to a person, which can be a natural person and/or a legal person according to

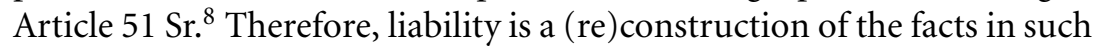
manner that legal consequences can be attached to acts or omissions of a natural person and/or legal person. This process is governed by rules and conditions of substantive law. For tort the basic requirements are laid down in Articles 6:162-3 BW and for crime the requirements for establishing criminal liability follow from the description of the specific offence in connection with the doctrine of criminal liability.

Article 6:162 BW in conjunction with Article 6:163 BW reads as follows: ${ }^{9}$

3 Utrecht L Rev 1, 6 and R. S. B. Kool, '(Crime) Victims' Compensation: The Emergence of Convergence' (2014) 3 Utrecht L Rev 14, 16-20.

${ }^{6}$ In essence this boils down to all crimes defined in the Dutch Criminal Code and in specific acts which set certain standards to protect, for instance, consumers, road-users, the environment, the financial markets. Of course, the legal order does not always offer redress for forms of reprehensible conduct. Obvious examples are having no manners, excessive billing, having a love affair during a marriage etc.

${ }^{7}$ In places (like the supervision of financial markets) there exists also liability according to administrative law, such as the imposition of an administrative fine or other administrative sanctions. These are alternatives to criminal liability due to the una via principle and the ne bis in idem principle. Apart from that, some unlawful acts have been decriminalised (like some road traffic offences) and are only punished by administrative sanctions. As this chapter focuses on tort and crime, we will not address this issue further.

${ }^{8}$ In Dutch criminal law, legal persons can be held criminally liable for the acts committed by natural person(s) in addition to the liability of those natural persons. The act or omission of the natural person(s) is then imputed to the legal person. However, for criminal liability of the legal person it is not required that the natural person who committed the crime is convicted or even prosecuted (see Art. $51 \mathrm{Sr}$ ).

9 Own translation, based on I. Giesen and E. F. D. Engelhard, 'Medical Liability in the Netherlands' in B. A. Koch (ed.), Medical Liability in Europe (Berlin: De Gruyter, 2011), 369-70. 
(1) A person who commits a tortious act (unlawful act) against another person that can be attributed to him, must repair the damage that this other person has suffered as a result thereof.

(2) A tortious act can either consist of a violation of someone else's right (entitlement) or an act or omission in violation of a duty imposed by written law or of what according to unwritten law has to be regarded as proper social conduct, always as far as there was no justification for this behaviour.

(3) A tortious act can be attributed to the tortfeasor if it results from his fault or from a cause for which he is accountable by virtue of law or generally accepted principles.

Article 6:163 BW reads:

There is no obligation to repair the damage on the ground of a tortious act if the violated standard of behaviour does not intend to offer protection against damage as suffered by the injured person.

The general definition of a criminal offence reads:

A criminal offence consists of an act or omission which falls within the terms of the definition of the offence which is ex ante laid down in a statute or regulation and which is unlawful and blameworthy.

This definition of a criminal offence is not laid down in an act, statute or whatsoever and does not have an official status; it is the general accepted definition in the doctrine. ${ }^{10}$ The elements of each crime are specified in the criminal offence, which is, as a consequence of the legality principle (Article $1 \mathrm{Sr}$ ), described in an act, statute or regulation (thus written law) and then interpreted by the courts.

When one compares both definitions of tort and crime important overlaps and important differences can be found. We will focus on two important differences but also provide an overview of the key similarities and differences in a table.

Both tort law and criminal law can establish liability for wrongs and harms. However, the kind of liability differs. In case of a tort, the law imposes on the tortfeasor the obligation to pay compensation to the victim. The Dutch Civil Code contains a group of seventeen articles which govern the legal duty to pay damages (Articles 6:95-110 BW). The basic principle is that financial loss, which covers the losses suffered as well as future losses and lost profits, must be compensated in full; on the other

10 See, e.g., C. Kelk and F. de Jong, Studieboek materieel strafrecht (Deventer: Kluwer, 2013), 61. 
hand, non-pecuniary damage is only recoverable if certain (restrictive) requirements set out in Article 6:106 BW (or specific legislation) are met. The latter provision offers victims, the right to financial compensation for their immaterial damage if the tort that gave rise to liability qualifies as an infringement to the victim's person. This is the case, for instance, if the victim suffers from a physical injury caused by the tort or damage to his reputation. In the case of a conviction for a crime the convicted person is held liable for the crime itself and sentenced: there are a variety of criminal sanctions, from imprisonment to the measure of paying a financial sum for illegally obtained profits to the state. ${ }^{11}$

However, tort law and criminal law are intertwined by a particularly Dutch phenomenon. Criminal courts can sentence the wrongdoer to pay compensation to the state for the benefit of the victim of the crime, the state collecting the compensation and passing it on to the victim. This criminal sanction, the compensation order of Article $36 \mathrm{f} \mathrm{Sr}$, is most commonly, but not in every case, imposed when the criminal court accepts the tort claim of the injured party. There are also a few other means in criminal law to effectuate compensation of the injured party, like the condition to pay compensation to the injured party as a specific condition to a conditional sentence or mediation. These instruments are significantly less frequently used than the compensation order. The compensation order's function is to insure that the victim receives compensation. The compensation order is, in a way, comparable to the responsibility of the tortfeasor in tort law to pay compensation to the victim. The result is the same: the victim of the crime is compensated for his damage caused by the crime. However, the way in which this obligation to pay compensation is executed differs. Since it is a criminal sanction, the state is responsible for the execution, which means that police and judicial powers can be used to force the convicted person to pay. More than this, if the convicted person does not have the financial means to pay compensation, the state has made itself responsible for compensating the victim. By contrast, in tort law the victim whose claim is granted by the court must enforce the court's order himself. This means that he must pay for a bailiff in order to make the tortfeasor pay and/or must use the procedures provided for in the Dutch Code of Civil Procedure. He also risks the defendant being unable to satisfy the claim.

${ }^{11}$ For an elaborate discussion of the Dutch sentencing system, see F. W. Bleichrodt and P. C. Vegter, Sanctierecht (Deventer: Kluwer, 2013) and for a brief overview J. F. Nijboer, 'The Criminal Justice System' in J. M. J. Chorus et al. (eds.), Introduction to Dutch Law (Deventer: Kluwer Law International, 2006), 399-444, at 421-4. 
There is another important difference between tort and crime, which concerns the flexibility of the system. Due to the principle of legality in criminal law, enshrined in Article $1 \mathrm{Sr}$, the definition of an offence must be laid down in an act, statute or regulation. The Dutch principle of legality is in this sense a bit stricter than the minimum standard of the European Court of Human Rights, which allows for a definition in the law, a concept that also encompasses case law. ${ }^{12}$ The principle of legality also contains a lex certa component, which demands that the legislature defines the criminal offence in a manner that is sufficiently precise and clear. So the act or omission (and any other relevant objective elements of the crime such as relevant circumstances) that constitute the offence must be defined clearly. This definition must be put in place in advance; it is the duty of the legislature to take care of a proper and adequate definition of the offence. For these reasons, offences can be found in the Dutch Criminal Code and specific acts, like the Road Traffic Act, the Act on Economic Crime and the Financial Markets Supervision Act. Tort law is more flexible. Article 6:162(2) BW provides for three criteria for unlawfulness, though admittedly these greatly overlap. Acts or omissions that belong to either one or more of these three categories are considered to be unlawful (unless there is a ground of justification). The three categories are:

(1) Breach of a legal right. Examples are breaches of real rights (rights in rem), like the property right, and personal rights, like the right to privacy.

(2) Acts or omissions that violate a statutory duty. These duties can be open standards in a statute like Article 7:453 BW: 'Medical practitioners must take all due care in the exercise of their profession in order to act as a good practitioner ...'?

(3) Acts or omissions that violate a rule or norm of unwritten law pertaining to proper social conduct. This category concerns a breach of a particular duty of care which is formulated specifically taking all the concrete circumstances of the case into account; in other words, a general duty of care. The Hoge Raad, the Dutch Supreme Court, has formulated four questions which can be used in cases that concern dangerous or risky activities to determine whether the duty of care has been breached: (i) the likelihood that one can expect that others are not paying the required attention or exercising sufficient caution; (ii) the chance that an accident might happen due to the

12 See, e.g., Scoppola v. Italy No. 2 (2010) 51 EHRR 12. 
defendant's actions; (iii) the severity of the consequences that can occur; and (iv) the extent to which it is either difficult or possible to take precautionary measures. ${ }^{13}$

The third category of unlawfulness particularly shows the open character of tort law and how Dutch tort law evolves through the work of the courts. Yet Dutch tort was not always arranged this way. This third category did not appear in the old Civil Code (1838) and the Hoge Raad interpreted the unlawfulness requirement narrowly: only a violation of a statutory rule could result in tort liability. ${ }^{14}$ This approach, which shows some resemblance to the core of the principle of legality in criminal law, was heavily criticised by scholars. In 1919 the Hoge Raad introduced the general duty of care, ${ }^{15}$ which was incorporated into the new Dutch Civil Code (Article 6:162(3) BW) of 1992. Since 1919, a huge body of case law with specific duties has been developed. This development is a manifestation of the structural tendency amongst Dutch courts to deduct the protected interests, standards of care and/or concrete rules in each individual case by identifying the relevant facts and putting a meaning on them. This process takes place in the interaction with already existing law. Subsequently, the courts decide the case on the basis of these interests, standards of care and/or concrete rules. In Dutch law, it is the courts, not the legislature, which are really establishing the boundaries of liability.

The first two categories for unlawfulness (legal rights and statutory duties) also require interpretation by the courts; they are not defined in Article 6:162 BW either. Over time, case law has set out more or less specific rules for unfair competition, defamation cases, liability in sports, traffic liability, employers liability, professional liability and other cases. It shows that this approach allows tort law to react in a made-to-measure fashion, with an opportunity to use 'local' knowledge and experience to identify and formulate the relevant standard of care on a case-by-case basis. ${ }^{16}$ Furthermore, the standards are inherently adaptable to changing

13 Hoge Raad 5 November 1965, NJ 1966, 166 (Kelderluik).

${ }^{14}$ Hoge Raad 6 January 1905, W. 8163 (Singer).

15 Hoge Raad 31 January 1919, NJ 1919, 161 (Lindenbaum/Cohen). About this development: G. E. van Maanen, De Zutphense juffrouw en de ontrouwe bediende van Lindenbaum (Nijmegen: Ars Aequi Libri, 1995).

${ }^{16}$ In our view, this is similar to the common law with its judge-made law. However, in Dutch tort law the courts have to start from an act, statute or regulation and there is, strictly speaking, no principle of precedent (that forces courts to follow previous case law in subsequent cases). 
circumstances, preventing rigidity. At the same time, since in these forms of wrongfulness the courts must start from an act, statute or regulation and their decision has to fit in existing (case) law, or at least, must explain why a new interpretation is given or a new rule is defined, they do not in principle breach the principle of legal certainty, even in cases where it concerns the general duty of care.

At the level of the elements of a tort and a crime the similarities and differences might usefully be summarised in Table 1:

Substantive Elements of Dutch Tort and Crime

\begin{tabular}{|c|c|c|c|}
\hline Requirement & Tort & Crime & Evaluation \\
\hline $\begin{array}{l}\text { Separate } \\
\text { definition in } \\
\text { a statute }\end{array}$ & No & Yes & $\begin{array}{l}\text { The legality principle } \\
\text { in criminal law } \\
\text { requires the definition } \\
\text { of offences in statutes } \\
\text { which is not the case } \\
\text { in tort law }\end{array}$ \\
\hline $\begin{array}{l}\text { Who? } \\
\text { (tortfeasor/ } \\
\text { suspect) }\end{array}$ & Any person & $\begin{array}{l}\text { In principle any person, } \\
\text { but in some cases persons } \\
\text { with a certain capacity or } \\
\text { position }\end{array}$ & De facto the same \\
\hline $\begin{array}{l}\text { Act or } \\
\text { omission }\end{array}$ & Yes & Yes & The same \\
\hline $\begin{array}{l}\text { Consequence } \\
\text { of the act or } \\
\text { omission? }\end{array}$ & Yes, damage & $\begin{array}{l}\text { Depends on the crime: } \\
\text { many crimes require } \\
\text { specific consequence, but } \\
\text { others do not (such as } \\
\text { theft, which does not } \\
\text { require proof that the } \\
\text { proprietor has lost his } \\
\text { property). }\end{array}$ & Not the same \\
\hline Causality & $\begin{array}{l}\text { Yes, the act } \\
\text { or omission } \\
\text { must result } \\
\text { in damage }\end{array}$ & $\begin{array}{l}\text { Depends on the crime: } \\
\text { causality is required when } \\
\text { the occurrence of a } \\
\text { consequence is an } \\
\text { element of the offence }\end{array}$ & $\begin{array}{l}\text { The same in case of a } \\
\text { crime with a causality } \\
\text { requirement }\end{array}$ \\
\hline
\end{tabular}

(cont.) 
(cont.)

\begin{tabular}{|c|c|c|c|}
\hline Requirement & Tort & Crime & Evaluation \\
\hline Unlawfulness & Yes & $\begin{array}{l}\text { Yes, though in many } \\
\text { crimes unlawfulness is } \\
\text { implied by the conduct } \\
\text { whilst in other crimes } \\
\text { unlawfulness is an } \\
\text { explicit element of the } \\
\text { offence }\end{array}$ & $\begin{array}{l}\text { More or less the same; } \\
\text { criminal law seems to } \\
\text { encompass more }\end{array}$ \\
\hline $\begin{array}{l}\text { Mens rea } \\
\text { element }\end{array}$ & $\begin{array}{l}\text { Negligence, } \\
\text { intent or no } \\
\text { mens rea } \\
\text { requirement } \\
\text { in case of } \\
\text { strict } \\
\text { liability }\end{array}$ & $\begin{array}{l}\text { Each crime requires } \\
\text { blameworthiness } \\
\text { (which is normally } \\
\text { assumed when the } \\
\text { perpetrator fulfils all } \\
\text { elements of the } \\
\text { offence); many crimes } \\
\text { require on top of that a } \\
\text { specific subjective } \\
\text { element (negligence, } \\
\text { dolus eventualis, intent } \\
\text { or even purpose). No } \\
\text { strict liability. }\end{array}$ & $\begin{array}{l}\text { Different system, with } \\
\text { different interpretations } \\
\text { of negligence and intent }\end{array}$ \\
\hline Relativity $^{18}$ & $\begin{array}{l}\text { Yes, see Art. } \\
6: 163 \mathrm{BW}\end{array}$ & No & $\begin{array}{l}\text { Relativity is necessary in } \\
\text { tort law to compensate } \\
\text { for tort's open character. } \\
\text { In criminal law there is } \\
\text { no such thing as } \\
\text { relativity: the definition } \\
\text { of the offences provides } \\
\text { the limits and is itself a } \\
\text { manifestation of a } \\
\text { certain norm or } \\
\text { standard that protects a } \\
\text { particular or general } \\
\text { interest }\end{array}$ \\
\hline
\end{tabular}

17 Dutch criminal law does not accept strict liability but administrative law does, sometimes with regard to offences which formerly belonged to the domain of criminal law, like some road traffic offences.

18 The rule that is violated should protect the victim's interests and the class of persons that he belongs to. E.g., road traffic rules only protect road-users, not someone who suffers a miscarriage from a sudden noise in the street. 


\section{How are the substance of crimes and torts related?}

Crimes and torts are related on a substantive level. We distinguish three levels at which this relation between crime and torts manifests itself.

On the first level, the function of criminal law and tort law is to deal with reprehensible behaviour. Although both serve several functions, they have in common that in the end they aim to control society by offering some form of redress. In tort law this redress is primarily offered to the claimant; Article 6:162 BW allows for damage caused by unlawful behaviour to be compensated by the tortfeasor. However, this also serves the public interest. In criminal law the focus of the redress is primarily on society at large. However, the picture is more complex because, as noted, criminal law can also offer redress to the victim. It does so by considering the injured party's claim at the criminal trial and imposing the sanction of compensation to the state for the benefit of the injured party, the compensation order, (discussed in detail in Sections 2 and 4.C.7). The different focus of the redress offered by tort law and by criminal law explains why tort law belongs to the domain of private law, particularly the law of obligations, which governs horizontal relations between citizens and/or private organisations/businesses, whilst criminal law is part of public law and deals with vertical relations between the governmental bodies on the one hand and citizens and private organisations/businesses on the other hand. There are related major differences in the functions of criminal law and tort law. For example, the preventive effect of criminal law as such is generally accepted, although there is discussion about which kind of prevention criminal law can offer and its effectiveness, ${ }^{19}$ while in

19 In Dutch criminal law, a distinction is made between general prevention and specific prevention. The general preventive effect is the impact of actual and perceived enforcement of the criminal law on society at large. When other citizens notice that reprehensible behaviour is prosecuted and sentenced, it is expected that they are deterred from committing crimes themselves, because they fear punishment (deterrence). At the same time, that process of adjudication confirms the rules and norms set by criminal law, or even re-sets them if there has been a new interpretation of a rule or norm. The specific preventive effect is the effect of application of criminal law to the perpetrator in three ways. First, he may be prevented from committing new crimes due to incapacitation (such as imprisonment, which removes the perpetrator physically from society, so he cannot commit another crime). This aspect also encompasses the function of safeguarding society from crime. Second, it is expected that the perpetrator will learn from his sentence and will refrain from committing new crimes in the future (deterrence). Third, with measure-made sentencing to the needs of the perpetrator he can acquire knowledge, education and skills to give him a new start in life after sentencing (re-socialisation). Thus, the preventive effect of criminal law encompasses not only several aspects of deterrence, but also more. See J. Remmelink, Mr. D. Hazewinkel-Suringa's Inleiding tot de studie van het Nederlandse 
tort law the preventive effect, through deterrence or otherwise, is heavily debated and the mainstream view is that prevention is not a function of tort law.

Second, crime and tort are related on the level of basic concepts and requirements. These similarities on the level of basic concepts and requirements also explain why a crime $=$ a tort. The classic example is the interpretation of the causality requirement in offences as well as in tort. In the 1970s the Hoge Raad decided that causation in tort (1970) and crime (1978) should be found by means of the standard of reasonable imputation. ${ }^{20}$ This standard entails that on the basis of grounds of reasonableness, it is considered to be fair that a specific consequence is attributed to a concrete act or omission. A second example is unlawfulness: one can say that more or less the same standard is used in criminal law and tort law. Where in tort law Article 6:162(2) BW provides for three overlapping categories of unlawfulness which are interpreted by the courts, in criminal law unlawfulness is only defined in the case law of the Hoge Raad. The Dutch Supreme Court uses the catch-all definition of an act or omission contrary to the law, which encompasses a violation of a written law (rule or norm) as well as a violation of unwritten law, like a rule or norm of unwritten law pertaining to proper social conduct. ${ }^{21}$ The scope of this definition is at least the same as the scope of the categories for unlawfulness in tort law, perhaps a bit wider thanks to its open character and the principle of autonomy of the criminal law, discussed below in Section 3.D. For this latter reason, unlawfulness in criminal law cannot be interpreted exactly the same as unlawfulness in tort law. ${ }^{22}$ However, one has to bear in mind that unlawfulness in criminal law is only one of the elements of a crime and that its open character is filled in the context of the specific elements of the crime in relation to concrete circumstances of the criminal case. ${ }^{23}$

The third level at which crime and tort are related, is how the elements which make up the offences and torts are interpreted. Interpretation is particularly important in criminal law, as interpretation by analogy or

strafrecht (Arnhem: Gouda Quint, 1996), 899-908; Kelk and De Jong, Studieboek materieel strafrecht, 26-27, 30-2.

20 See for tort law Hoge Raad 20 March 1970, NJ 1970, 251 (Doorenbos v. Waterleidingsgebied Leeuwarden) and for criminal law Hoge Raad 12 September 1978, NJ 1979, 60 (Fatale longembolie). See Section 3.D for a brief discussion.

21 Hoge Raad 9 February 1971, NJ 1972, 1 (Dreigbrief).

22 J. de Hullu, Materieel strafrecht (Deventer: Kluwer, 2012), 190.

${ }^{23}$ Ibid., 191; Kelk and de Jong, Studieboek materieel strafrecht, 153-65. 
even too extensive interpretation would breach the principle of legality. Many definitions of offences use terms which are also used in private law. If there is value in a uniform interpretation of a term across private and criminal law, the question arises whether the element of the offence which is defined with the same terms as used in private law should be interpreted in the same way as in private law. However, we will show in the next section that historically a clear distinction has been made between tort and crime, and that in criminal law the principle of autonomy exists, allowing criminal courts to give their own interpretation to terms which are also used in private law.

\section{Why are tort and crime so (un) connected?}

First and foremost it must be stressed that the 'relationship' between tort and crime is not dealt with in the Netherlands in terms of either 'equality' or 'hierarchy'. This terminology is basically not used at all. The tort system and the criminal justice system are considered to be two distinct areas of law that intertwine at some points. This follows from the principle of autonomy, discussed below. Given this context, the relation between the tort and crime is not further analysed in terms of a 'relationship' or 'what comes first'.

The foregoing sections show that tort and crime are not so connected as one would expect given the historical background of tort and crime. In Roman law and Medieval law there was no distinction made between crime and tort. A natural person could be held liable for reprehensible behaviour that was prescribed by statutes and rules, which also set out specific sanctions. ${ }^{24}$ Slowly tort and crime developed into separate areas of law. One could pinpoint the opinion of Hugo de Groot, who in 1631 made a clear distinction between sentencing in criminal cases and paying damages in tort law cases, as a starting point for this development of tort and crime as separate areas of law. ${ }^{25}$ This development expanded enormously with the codification of rules and norms of private law and criminal law in the Napoleonic Codes which were applicable during the French dominion over the Netherlands from 1810-13, which followed a period starting from 1795 where the Netherlands were a vassal state of the

24 A. S. Hartkamp and C. H. Sieburgh, Mr. C. Assers Handleiding tot de beoefening van het Nederlands burgerlijk recht. 6. Verbintenissenrecht. Deel IV. De verbintenis uit de wet (Deventer: Kluwer, 2011), nos. 3-4.

25 Ibid., no. 5. 
First French Republic. The French Code Civil (1804), Code Pénal (1810) and Code d'Instruction Criminelle (1808) were shortly prolonged after the French dominion and gradually replaced by Dutch Codes in 1838, which, however, were at least inspired by the Napoleonic Codes. The Dutch Civil Code of 1838 and the Dutch Code of Criminal Procedure of 1838 featured the dogmatic distinction between tort and crime which is characteristic of the substantive Napoleonic Codes. ${ }^{26}$ However, this dogmatic distinction began to unravel.

Already by 1838 the Dutch Code of Criminal Procedure offered the victim of certain crimes, which were only the crimes dealt with by the courts in correctional cases (the ordinary crimes like theft, the so-called wanbedrijven), the possibility to join the criminal proceedings if his claim for damage was below 68 Euros and not pending before a civil court (Art. 231 Sv 1838). These strict conditions were inspired by the distinction between tort and crime, according to which the criminal court does not have jurisdiction over issues of private law, while at the same time the criminal court should not be distracted from the principal issue, namely deciding the criminal case, so the tort claim must be very simple and was considered as something 'additional. ${ }^{27}$ This rationale must be seen against the background of the legislature's wish not to copy from the French Code d'Instruction Criminelle the right of the injured party to start prosecution. Only the Public Prosecutor's Service should have the (monopolistic) power to prosecute. ${ }^{28}$ With the amendments of the Code of Criminal Procedure in 1886 the offence limitation, restricting the process to certain crimes was removed, thus all crimes (even serious offences or misdrijven ${ }^{29}$ were covered. In addition, the effective position of the injured party was improved (for instance with the possibility of

${ }^{26}$ See for this dogmatic distinction, e.g., J. de Bosch Kemper, Wetboek van Strafvordering, Eerste deel (Amsterdam: Johannes Müller, 1838), 47-54; J. Slingenberg, De strafbare daad en de schadeloosstelling van den benadeelde (Amsterdam: Delsman and Nolthenius 1896), 96-8. Compare the similar distinction in the French and German legal systems. Note the Burgerlijk Wetboek (BW) was revised in 1992, the Wetboek van Strafvordering (Sv) in 1926 after a partial revision in 1886. A following revision of the Wetboek van Strafvordering is planned and will be executed in near future.

27 See J. de Bosch Kemper, Wetboek van Strafvordering, Eerste deel, 47.

28 Ibid., 51-2.

29 The new Criminal Code of 1886 abolished the distinction between very serious crimes like capital crimes (misdaden), ordinary crimes like theft (wanbedrijven) and minor or petty offences (overtredingen) and introduced the twofold distinction between crimes (i.e. serious offences) and minor or petty offences. 
legal assistance). However, the same limitations to the admissibility of the claim for damages of the victim of crime in criminal proceedings, claim limitation, were kept on basis of the initial rationale. ${ }^{30}$ Even on the introduction of the current Code of Criminal Procedure in 1926, the claim limitation of 68 Euros was retained for the same reasons; though the limitation that the claim was not yet pending at the civil court was removed. ${ }^{31}$ The monetary limitation to claims with a maximum of 68 Euros, which had in 1954 been raised to 136 Euros, then to 226 Euros in 1963 and subsequently in 1978 to 680 Euros for cases pending at district courts, ${ }^{32}$ was removed in 1995 with the coming into force of the Terwee Act. This Act introduced a qualitative criterion instead (see further Section 4.C).

It follows from the historical origins of the current procedure of the joinder of the injured party's claim for compensation in criminal proceedings that tort and crime have always been intertwined. In particular, based on a mix of compassion and efficiency, the victim, as an injured party, was (and still is) entitled to bring forward a (simple) civil claim for compensation to be handled by the criminal court. ${ }^{33}$ Traditionally, this procedure is considered to be ancillary in two respects. First, the tort claim is dependent on the criminal law as only the victim who directly suffered damage as a consequence of a crime can use the procedure. Second, the handling of the claim is subordinate to the criminal proceedings. ${ }^{34}$ However, there is a trend to focus on the position of victims of crime and to improve the victim's chances of obtaining compensation. We will discuss it in detail in Sections 4.A and 6.

An important explanation for the lack of connection between tort and crime is the principle of autonomy. According to this principle criminal

${ }^{30}$ See H. J. Smidt and E. A. Smidt, Wetboek van Strafvordering met de geschiedenis der wijzigingen daarin gebracht bij de invoering van het Wetboek van Strafrecht, Deel I (Haarlem: H. D. Tjeenk Willink, 1886), 583-4, 588-9.

31 A. J. Blok and L. Ch. Besier, Het Nederlandsche strafproces, Tweede deel (Haarlem: H. D. Tjeenk Willink, 1925), 113-15.

32 See the Act of 4 May 1954, Staatsblad 1954, 169, the Act of 20 November 1963, Staatsblad 1963, 485 respectively the Act of 10 October 1978, Staatsblad 1978, 528. The only reason for raising the monetary limitation was to adjust for inflation, see Parliamentary Papers 1962-3, 7101, no. 3, p. 6 respectively Parliamentary Papers 1977-8, 15 019, nos. 1-3, p. 13.

33 R. S. B. Kool, 'Comment 2 at Arts. 51a-51h' (suppl. 178, November 2009) in A. L. Melai and M. S. Groenhuijsen et al. (eds.), Het wetboek van strafvordering (Deventer: Kluwer (loose leaf edition)).

34 M. S. Groenhuijsen, Schadevergoeding voor slachtoffers van delicten in het strafgeding (Nijmegen: Ars Aequi Libri, 1985), 33-4. 
law has its own functions and purposes from which it follows that criminal courts can and must decide on crimes themselves and this demands an autonomous interpretation of the elements of offences. It means that they have the discretionary power to abstract from rules, norms, interpretations and concepts of private law. When criminal courts would be bound by those rules, norms, interpretations and concepts of private law, it may hinder the purposes of criminal law and therefore harm the functions of criminal law. Criminal law should determine itself in which cases and under which conditions someone can be held criminally liable, which criminal sanctions can be imposed and by which criminal proceedings this is realised, thereby observing the principles, concepts, norms and rules of criminal law (such as the principle of legality and guilt principle). This also implies that criminal courts can decide on issues of private law that have to be decided in order to judge a criminal case. ${ }^{35}$ The principle of autonomy stems from the development of tort law and criminal law as separate areas of law. Remarkably, the principle is generally accepted in criminal law, but not as such recognised in private law; private law is considered to be autonomous in se. As we will demonstrate below, there are provisions in Dutch law that express the principle of autonomy, like the rule of Art. $14 \mathrm{~Sv}$ that a criminal court can adjourn the proceedings in order to await the outcome of civil proceedings, but the criminal court is not obliged to do so and has thus the power to decide the private law issue itself (see Section 4.B).

The existing connections between tort and crime have often been triggered by reasons of pragmatism and/or coherence. For instance, the identical interpretation of causation in tort and crime amply demonstrates both reasons. First, it is very difficult to transform the concept of causality into a workable standard for the courts to establish whether the causality requirement is met in a concrete case. In the doctrine several theories about causation have been developed and continue to be. The legislator left it, for reasons of pragmatism, open to the courts to decide what the causality requirement should entail in tort as well as in crime. The legislature made clear by 1886 that it was not able to draw up a general criterion with which the causality requirement could be applied in tort and in

35 H. A. Demeersseman, De autonomie van het materiële strafrecht (Arnhem: Gouda Quint, 1985), 565-79, 608, 610-11, 618-19, 643-4; F. G. H. Kristen, 'Comment 4.4 at Art. 14' (suppl. 118, October 2000), in A. L. Melai and M. S. Groenhuijsen et al. (eds.), Het wetboek van strafvordering. 
criminal cases. ${ }^{36}$ After a development in the case law, the private law chamber of the Hoge Raad first decided in 1970 that the causality requirement in tort should be decided with the standard of reasonable imputation. ${ }^{37}$ Eight years later the criminal law chamber of the Hoge Raad followed and decided that the same test for causation should be used in criminal law. ${ }^{38}$ Although the court did not made explicit for which reasons it followed the approach of the private law chamber of the court (it was not required to do so), it has been assumed that the standard developed by private law chamber was workable and it would contribute to the coherence between tort and crime to use the same standard in criminal law. Such coherence can also enhance legal certainty. However, it must be remembered that this only concerns the standard to be used to establish causality in criminal cases and civil cases; the law of evidence and particularly the standard and burden of proof are different in criminal procedure and civil procedure (see Section 5.B). This obviously affects the application of the causation standard.

\section{Criminal Court $\approx$ Civil Court}

\section{A. Introduction}

1. Context: increasing attention on compensation for victims of crime

Drawing up a clear description of the interaction between tort and crime in Dutch procedural law is rather a challenge. While there is, in practical terms, procedural overlap, there is at the same time a strong element of autonomy for each of the rules of civil and criminal courts. Recent legislative interventions to encourage the award of compensation to victims of crime and simultaneously provide for procedural justice show an increasing attention to this topic. These interventions bypassed the traditional opinion that no 'private' element whatsoever must be admitted

36 See for criminal law H. J. Smidt and J. W. Smidt, Geschiedenis van het Wetboek van Strafrecht, Deel I (Haarlem: Tjeenk Willink, 1891), 138. The Minister of Justice remarked during the deliberations on the bill for the Criminal Code: 'It is incontestable that no legislator has it within his powers to prevent the variety of questions which raise in connection with criminal liability or civil liability by means of providing for a definition of causation' (authors' translation).

37 Hoge Raad 20 March 1970, NJ 1970, 251.

38 Hoge Raad 12 September 1978, NJ 1979, 60. 
within criminal proceedings: the victim had, for instance, traditionally been barred from having a distinctive place the criminal trial. Nonetheless, compassion had driven the Dutch to allow victims to bring small claims through the adhesion procedure. ${ }^{39}$

It was in the 1990s that a shift of the penal paradigm became manifest. Except for the introduction of the adhesion procedure at the beginning of the nineteenth century (see Section 3.D), there had not been much of a debate with regard to victims' compensation. ${ }^{40}$ Due to a rise of traffic accidents, debate rose in the 1960s, but the real trigger for the paradigm shift in the 1990s lies in the work of the Law Reform Commission on Financial Penalties (1969). ${ }^{41}$ This committee, chaired by the penal abolitionist Hulsman, ${ }^{42}$ recommended a fundamental re-orientation of the concept of sanctioning, focusing on conflict solving instead of the traditional aim of prevention and deterrence. The approach of the committee, however, was academic rather than immediately practical, focusing on behavioural aspects, pursuing re-socialisation by 'civilising' the criminal law. In the years to come, other law reform commissions would also addressed the victims' position, however but without yielding practical results.

Meanwhile, in the wake of secularisation and individualisation, the idea of 'citizenship' has changed. In the past decades, the Dutch society has fragmented, experiencing a decline of authority and individualisation. This has, amongst other things, been accompanied by a strong call for state protection, featuring a collective rejection of victimhood..$^{43}$ Selfhelp organisations were set up, ultimately leading to the formation of the Dutch Victim Aid Organisation that was founded in 1984. A year later

39 This position reflects the profile of the Netherlands as a 'high-trust society', featuring a 'politics of accommodations' (pursuing political consensus by negotiation), implying a high esteem in the authorities. E.g. A. Lijphart, The Politics of Accommodation. Pluralism and Democracy in the Netherlands (University of Berkeley Press, 1975); C. de Voogd, Geschiedenis van Nederland (Amsterdam: Arena, 2000).

40 See for a brief description Section 3.D above. For an overview: Kool, 'Comment 2 at Arts. 5la-51h' (suppl. 178, November 2009).

${ }^{41}$ Commissie Vermogensstraffen, 'Het Strafrecht en de benadeelde partij. Tweede Interimrapport' in: Eindrapport van de Commissie Vermogensstraffen (The Hague: Staatsuitgeverij,1972), appendix IV.

${ }^{42}$ Louk Hulsman was professor of criminal law at the Erasmus University Rotterdam. He was inspired by the work of Thomas Matthiesen and Nils Christie. Except for the report mentioned, his work has not deeply influenced the Dutch debate. Nevertheless, his work is reflected in the topical introduction of restorative justice schemes.

${ }^{43}$ H. Boutellier Solidariteit en slachtofferschap (Nijmegen: SUN, 1993). 
Groenhuijsen, who would become the key player in the academic victim's movement, published his thesis on victims' compensation. ${ }^{44}$ Finally, the women's movement came into play, waging an active campaign against sexual violence. One aspect of this was arguing that women and minors were in need of adequate legal protection, including being entitled to redress for wrongs. ${ }^{45}$ Subsequently, the Public Prosecution Service initiated ad hoc committees to consider victims' need and make recommendations, amongst others on compensation. ${ }^{46}$ In the wake of these social and legal changes, a law reform commission, the Terwee Committee, was set up in 1985. This committee considered the convergence of tort law and criminal law, recommending, amongst other things, a raise in the value of the claim limitation, a simplification of the admissibility criterion and the introduction of a new form of punishment, the schadevergoedingsstraf (compensation penalty). The latter recommendation was innovative, as it suggested that a criminal offence can constitute both criminal and civil liability, to be assessed in the context of the criminal proceedings. ${ }^{47}$ This proposal, however, was rejected: the legislature opted for a compensation order instead (Article 36f Sr). Since then, developments in the area have been concentrated on the legitimacy and consequences of upholding the crime victim's legal rights, including an improvement of the right to claim compensation. Yet this has not fundamentally altered the Dutch law's scope of the victim's formal position, in particular, victims still are not granted a procedural position on equal footing with the defendant or the Public Prosecution Service. To date, the victim is acknowledged as a participant, but not as a 'party'. The latter is a 'breaking point' within the Dutch scheme of justice. Indeed, although the Dutch government highly values the victims' interests, acknowledging the victim as a principal stakeholder having legal rights, ${ }^{48}$ and is moreover showing eagerness to

${ }^{44}$ Groenhuijsen, Schadevergoeding voor slachtoffers van delicten in het strafgeding.

45 A. C. Zijderveld et al., 'De wisselende aandacht voor slachtoffers. Enkele cultuursociologische overwegingen', in Handelingen Nederlandse Juristenvereniging, Het opstandige slachtoffer (Deventer: Kluwer, 2003-I), 1-33.

46 According to the case-law such recommendations count as substantive 'law' ex Art. 79 RO and must be pursued (Hoge Raad 27 May 2014, ECLI:NL:HR:2014:136).

47 Note the Dutch criminal law uses a bifurcated concept of sanctions: punishment (straffen) and measures (maatregelen). Generally speaking, the first category is based on retribution, requiring a mens rea element; the latter is in pursuit of public protection.

48 Title IIIA Sv provides an extended catalogue of victims' rights, covering a wide range of interest, e.g. with regard to treatment (Art. 51a Sv), disclosure (Art. 51b Sv) and legal assistance (Art. 51c Sv). 
further the facilities with regard to compensation, ${ }^{49}$ there is no intention to extend the formal position of the victim.

Indeed, the adhesion procedure - to be discussed below - must not be confused with the right to prosecute, for the Dutch system does not hold a right for private prosecution. The right to prosecute rests exclusively with the Public Prosecution Service. Moreover, the Public Prosecution Service is not obliged to prosecute (Arts. 167 and $242 \mathrm{~Sv}$ ) rather they exercise a discretion, only prosecuting when they view it as being within the public interest. Double jeopardy, that is, initiating criminal proceedings more than once for the same fact, is prohibited in the Dutch system (Art. 68 Sr) ${ }^{50}$ If, however, the Public Prosecution Service abstains from prosecution, the victim can request a review by the Court of Appeal of that decision to abstain (Art. $12 \mathrm{~Sv}$ ). In cases where the complaint is upheld, the Public Prosecution Service must prosecute. ${ }^{51}$ The reason to opt for the Court of Appeal as the reviewing authority, instead of the Court of First Instance (here, the District Court) is because of the position of the Public Prosecuting Service in the Netherlands: the Public Prosecution Service and the District Court are on the same level of seniority. Thus the legislature wanted to prevent a conflict of authority. ${ }^{52}$

\section{The legal routing}

Facts can be brought to court by using different routes. In general, conflicts of jurisdiction are settled within the relevant codes ( $\mathrm{Sv}, \mathrm{Rv}$, Code of Judicial Organisation (RO)). There is, however, no formal hierarchy between the distinct sections for the legal issues ruled upon are autonomous

49 The latter development, however, relates to furthering both the criminal law and the civil law facilities.

50 As will be discussed under Section 4.C, the criminal courts are instructed to avoid ruling the claim to be unfounded, and to opt for an estoppel in order to grant the victim the opportunity to bring the claim before a civil court.

${ }^{51}$ Next, the victim (or his/her relatives) has the 'right' to request a second opinion regarding the judicial investigation. However, this is no legal right, but one based upon policy of the Public Prosecution Service (directives).

52 Note the Public Prosecution Service is a hierarchical organisation, with different representatives associated with the different levels of courts. On the level of the Court of First Instance, the members of the Public Prosecution Service are called 'officier van justitie', on the level of the Court of Appeal they are addressed as 'advocaat-generaal. Next, there is the 'advocaat-generaal' and (one) 'procureur-generaal' at the level of the Hoge Raad. The role of individuals in these last two categories differs, however, since they do not initiate public prosecution, expect for a limited category of offences. Their primary task is to advice the Hoge Raad. 
(see Section 3.D). An earlier judgment does not bind findings in later courts, assuming that these courts operate in different fields of law. The point of departure is the 'claim': the claim for prosecution being of a different nature from the claim for compensation, the civil and the criminal procedures address different elements of legally relevant behaviour. Notwithstanding that there are mutual points of reference (for example, the prerequisite of an activity or omission and an element of blameworthiness), ${ }^{53}$ the legal standards used to assess tort and crime differ (see in this respect the remarks about the different focus in functions of criminal law and tort law in Section 3.C).

Thus the criminal court can - but as a rule will not - ignore a relevant ruling of a civil court and vice versa. ${ }^{54}$ Indeed, the Dutch Code of Criminal Procedure also offers a criminal court the discretion to postpone its decision in order to await a decision of a civil court on a matter which is of importance for criminal case (Art. $14 \mathrm{~Sv}$ ). The aim of this technique is to prevent different interpretations of the law. In practice courts seldom apply this rule. Although this is no hard and fast rule in civil procedural law, a similar management technique exists for the civil law (see also Section 5.C).

Nevertheless, notwithstanding that the civil and the criminal court assess cases autonomously, procedural regimes regarding compensation for tort or crime can overlap. For example, as already noted, a tort can be subject to both criminal and civil procedure simultaneously though it rarely happens in practice. Another possibility, though very rare, is that the civil court might decide its case first. If this civil court accepts or rejects the whole of the claim, the victim will be estopped from bringing any later civil and criminal action because her interest will be extinguished. ${ }^{55}$ However, there is also the more common situation in which a criminal court admits only part of the claim, rejecting those parts which were unduly burdensome (discussed further below, Section 4.C.2). In this case, a judgment from a criminal court on those elements would still leave some interest which the victim could pursue with

53 We abstain from discussing compensation with regard to strict liability (Art. 6:169 BW); the criminal law does recognise such a category, but only for the minor offences (misdemeanours).

${ }^{54}$ F. G.H. Kristen, 'Comments 4 and 9 at Art. 14' (suppl. 118, October 2000) in A. L. Melai and M.S. Groenhuijsen et al. (eds.), Het wetboek van strafvordering.

55 An interlocutory injunction, not being a final ruling, also allows the criminal court to rule on a civil claim brought before the civil court. (HR) 19 February 2010, ECLI:NL:HR:2010:BK9301. 
a later civil claim. There is a pragmatic argument underlying this informal 'hierarchy': a criminal ruling provides compelling evidence in civil cases (Article $161 \mathrm{Rv}){ }^{56}$

\section{B. Where is the overlap (or the difference)}

As is commonly the case in a civil law system, which place great importance on the principle of legality, it is the legislature who decides whether a particular rule in an act or statute will belong to the civil or criminal law. An offence by definition implies a contravention of a statutory rule; by virtue of Article 6:162 BW, the latter also qualifies as a tort. Of course, it should not be forgotten that a tort can also consist of a violation of another person's right, caused by an activity or omission that has, according to unwritten law, to be regarded as improper social conduct (see Section 3.B). As regards the creation of legislative rules, generally proposals to introduce statutory law come from the Ministry for Security and Justice (MSJ). However, there is a possibility for initiatives by Members of Parliament (Lower House only), though this is rare. ${ }^{57}$ The MSJ has a specific section that prepares Bills, with subsections with regard to the specific legal areas. The civil servants assigned to develop and execute the government's policy are consulted. As a rule, the MSJ consults the State Council, as well as other advisory boards (e.g., the Board for the Judiciary, the Public Prosecution Service and the Bar Association).

Civil law, including tort claims amongst others civil wrongs, on the one hand and the criminal law on the other are traditionally separated areas of the law (see also Section 3.D). This separation already starts at the universities: most law faculties offer a bachelor programme in law with separate courses in private law, criminal law, constitutional and administrative law and European and international public law. The distinction between tort and crime is thus already set down before students graduate. This division flows from the legislator setting down requirements to enter legal practice as a solicitor/barrister, public prosecutor or judge: students must have what is known as civiel effect. This in turn requires a bachelor's and master's degree which included separate courses in at least private law, including civil procedure, and criminal law, including

${ }^{56}$ Nevertheless, the 'compelling evidence' needs to be put into perspective so that the defendant can try to rebut the evidence by bringing counterevidence (Art. 151(2) Rv). See also above.

57 The Higher House does not have the right to initiate, nor does it has the right to make amendments. 
criminal procedure, as well as one of constitutional law, administrative law or tax law. ${ }^{58}$

There are also separate branches within the District Courts, Appellate Courts and the Hoge Raad. ${ }^{59}$ First, who can bring a claim? Anyone who has a justified interest can bring a claim before the courts. A justified interest implies the appellant claims to have had a right violated that was protected by the law (the procedural condition of relativity). As for who hears the claim: for the District Courts and the Courts of Appeal, these consist of a single professional judge (so-called politierechter), or three professional judges (meervoudige kamer). ${ }^{60}$ Courts are divided into branches. The criminal branch of a court deals with crimes, while the civil branch of that same court deals with civil cases. ${ }^{61}$ Nevertheless, particularly at the level of the District Courts, the judges circulate roughly every four years. However, they only alternate between two distinct law areas, such as criminal law and administrative law or criminal law and family law or criminal law and commercial law. The Public Prosecution Service can play a role in any of civil procedures but this is a rare exception indeed. ${ }^{62}$

The majority of the cases in the Netherlands concern private law disputes of all sorts (labour, rent, contracts, tort etc.). After that, criminal law

58 See for instance Art. 2(1)(a) Act on Advocates (Advocatenwet) in connection with Art. 1 Besluit beroepsvereisten advocatuur, Staatsblad 2005, 48, which requires that the final exam of a bachelor's and master's programme must contain a criminal law course, which must also include criminal procedure, as well as a private law course, which must also include civil procedure.

59 Note the Hoge Raad also has a tax chamber. Traditionally, the Hoge Raad functions as a court of 'third instance', however, not ruling upon the facts. An application to cassation thus can be filed after a case has been tried at first and second instance. In order to limit the case-load a selection-rule has been introduced recently: Art. 80a(1) RO allows the Hoge Raad to declare an appeal inadmissible if this does not serve an interest of the claimant, or would not benefit the development of the law. Note, victims whose claims have been rejected by the appeal court in the context of an adhesion procedure (see Section 4.C), are not entitled to appeal the Hoge Raad (Art. 473(3) Sv). If, however, the Public Prosecution Service and/or the defendant appeal(s), the victim's claim is allowed to follow.

${ }^{60}$ Note, in appeal the single judge is not called politierechter, but enkelvoudige kamer (single chamber).

${ }^{61}$ The civil law being wide, the civil court is organised in subsections (e.g., family law or commercial law). Next to the civil law and the criminal law sections, there is an administrative law section.

${ }^{62}$ The common denominator is that there is a 'public' interest to take care of, for instance placing a juvenile into civil care, or requesting a bankruptcy, followed by an annulment of a legal person. See: M. E. de Meijer, Het Openbaar Ministerie in civiele zaken (Deventer: Kluwer, 2003). 
has become perhaps the next most significant major specialisation within legal practice. Since both fields are individually so large, not many people work in both fields. While practitioners tend to specialise in a specific area of the law, this is represented by an agreed list of skills and abilities particularly important for either tort or crime. Nevertheless, practitioners have to periodically apply for additional courses in order to be entitled to work as a barrister, prosecutor or judge. There are also associations for lawyers, associations which specialise in a certain field (and who impose a certain measure of expertise) but membership is not needed in order to take on a case in that field. There are, however, two situations which do require specialist training. First, cassation-procedures are executed by a group of specialised lawyers who have undergone specific training. ${ }^{63}$ Second, due to the rise of the victim, the group of barristers handling tort cases, including in the context of a criminal procedure, has increased. Indeed, the LANGZS Foundation, a group of barristers specialised in providing legal assistance to victims of crime who seek reparation, was invited to develop a training programme, perhaps indicating a new branch of the bar. Barristers who have been assigned for legal aid assistance to crime victims must have undertaken this training programme. ${ }^{64}$

\section{How are tort and crime procedurally related}

Any overview of the procedural aspects of the relationship between tort and crime inevitably touches upon aspects of the substantive law. This follows logically from the systematic positioning of the claim for compensation ex Article 51f Sv: the victim lodges a civil claim within a criminal procedure, obliging the criminal court to deal with the criminal allegation and, within limits, civil compensation. This avenue for claiming compensation is the so-called adhesion procedure or joinder as injured party (vordering benadeelde partij). There are no accurate statistics available on in how many criminal cases victims use the adhesion procedure and

${ }^{63}$ For the criminal law section this training is not obligatory. However, in practice cassationlawyers practicing criminal law do take such a training programme. Cassation is a process which focuses on appeals of law, not on the details of fact, and the superior courts may require more rigour, time-keeping and precision so this training is hardly surprising.

64 Actually, there are two training programmes and only the first is obligatory: a basic one with four to five meetings and a specialised one with seventeen meetings. The first is required to be assigned legal aid cases; the second one is required to sign up as a specialised victim's barrister. Roughly twenty candidates will take these training programmes on an annual basis. After the initial start, however, these training programmes will probably be offered every two years. 
what the outcomes of those procedures are. However, some (qualitative) studies show that in a significant number of criminal cases in which there is a victim, and which were decided by a district court at first instance, the adhesion procedure is used. In our interpretation of the available data it concerns approximately 31 per cent of such criminal cases. Of those cases, the court granted compensation, in whole or in part, in approximately 65 per cent of the cases. ${ }^{65}$ This represents what we think of as Dutch pragmatism.

\section{The adhesion procedure (Article 51f Sv)}

If the case is brought before the court, Article $51 \mathrm{f}$ Sv allows the victim of a crime who suffered damage directly from the crime to bring a claim for that damage before a District (Criminal) Court. In that case the victim is joining criminal proceedings as the 'injured party'. While there is no longer a claim limitation on the amount of compensation, there are other limitations. In the first place, complex claims will be rejected. Thus, for instance, where he suffers a number of types of loss, he might select to bring only the part which relates to a simple part, bringing the complicated part in front of the civil court (see Section 5.C). In this way, the injured party pre-emptively seeks to avoid the risk that the claim will be grounded inadmissible by the criminal court due to the complicated nature of the claim. If the injured party does not do so, the criminal court itself can split the claim, ruling it to be partially inadmissible (Article 361(3) Sv). Although seldom used, the criminal court can also rule a claim to be inadmissible in advance, thus giving a preliminary ruling.

Nevertheless, there may be some overlap between how civil and criminal courts award compensation. Some judges are willing to award such a claim in terms of 'an advance', leaving it to the victim to start a civil procedure to claim the remainder. Nevertheless, this is not general practice. Moreover, the term 'advance' is not well chosen as the ruling by the criminal court is final, indicating this part of the claim cannot be subject

65 The figures concern 2010. That year the district courts dealt in first instance with 110,000 criminal cases (source: CBS Statline, www.cbs.nl (last accessed November 2014)). In 54,000 cases there was a victim. In 17,000 cases the district courts decided on the claim and in 11,000 cases the court awarded the claim in whole or in part (source: W. Schrama and T. Geurts, Civiel schadeverhaal door slachtoffers na strafbare feiten (The Hague: WODC, 2012, no. 1), 70-2. For a qualitative study with comparable results, see M. R. Hebly et al., 'Crime Victims' Experiences with Seeking Compensation: A Qualitative Exploration' (2014) 3 Utrecht L Rev 27. To put it in perspective: in 2010 there were 209,000 criminal cases recorded at the level of the first instance and almost 1,200,000 crimes (that is without the misdemaenours) registered (CBS Statline). 
to a civil procedure. It was chosen to suggest the idea that the sum was, like a publishing company's initial payment towards a promised book, a way for the victim to be in a secure enough financial position to proceed with a civil claim for the full amount in front of a civil court.

The civil claim can be brought at any time once the indictment has been laid until it is presented by the public prosecutor in court. In practice, the Slachtofferloket, which forms part of the Public Prosecution Service, must inform the victim in advance about the right to lodge a claim, sending the victim a standard-form (Article $51 \mathrm{~g} \mathrm{~Sv}$ ) ${ }^{66}$ As a rule, the Slachtofferloket receives information from the police, who, as a rule, inform the victim of his rights, including the right to claim compensation. The victim's wish to request compensation, is then reported to the Slachtofferloket, present at the level of the District Courts and Regional Courts. However, the victim is not obliged to use this form. Indeed, the victim can choose to attend the trial and bring the claim forward in person. Nevertheless, in practice the courts do have a strong preference for the use of the standard form, and the victim might be requested to use one. Although the majority of the claimants do use the form, and the idea is that the forms should be annexed to the dossier before the trial, in order to enable the defence, the public prosecutor and the court to prepare an opinion with regard to the claim, this tends to happen only a few days before the trial is scheduled. From the court's perspective, looking to the defendant's interests - this is rather late, causing a risk that the claim will be ruled inadmissible. In order to further the chances of success, however, the forms are reviewed before the trial by a controller, in service of Slachtofferhulp (Victim Support). ${ }^{67}$ Although such a review is not obligatory, it is important. If that review finds that the claim needs further evidence, it gives the claimant more time to find it and present it at the trial. However, in practice such a review is limited to complex claims, and with regard to victims who do not have legal assistance. The court itself will not slow down the prosecution so the claimant can find it. That said, there is one situation where the court can and does adjourn, which is where a claimant has informed the Public Prosecution Service of his/her wish to attend trial in order to elucidate the claim, and the Public Prosecution Service has not given notice of

66 The standard-form covers a range of items relating to the victim's interest, amongst others the victim's wish to claim compensation. Other topics are, amongst others, the wish to stay informed and the wish to make us of the right to make an oral statement in court.

67 These controllers are posted within the local Public Prosecution Service office, located in the court building. Slachtofferhulp is an NGO, financed by the Ministry of Security and Justice; the controllers are on the pay-role of Victim Support. 
the trial. Note the claimant is not obliged to pay a court fee, nor to be present or to be represented in court. If, however, the victim chooses to be represented by a barrister (Art. 51c Sv), the barrister must be paid ${ }^{68}$ with the fees being based on the claimant's income. ${ }^{69}$ Article 44, Wetop de Rechtsbijstand (Code on Legal Assistance), however, grants victims of sexual crimes or violent crimes, or, if the victim has deceased, his or her relatives, free legal assistance.

Quite remarkably, Article 51f Sv also allows claims to be brought to the court for acts that are not mentioned in the indictment, but which are related to it as subsidiary facts. If the defendant admits to having committed these offences (ad informandum gevoegd feit) they are added to the indictment, but they benefit from a sentencing reduction. ${ }^{70}$ This legal construction is not without risk for the defendant, for although he is entitled to sentencing reduction, he also risks having to pay compensation for any harm proven. While his consent does imply a waiver of the right to oppose to these claims on the facts, any civil claim will not be dealt with in detail at trial so he will have limited opportunity to contest it.

\section{Admissibility, the 'ten minute rule'}

Whether the claim will be ruled admissible depends on its complexity. In practice, the judge uses the 'ten minute-rule': if the court is of the opinion that the handling of the claim will take more than ten minutes, it will be ruled inadmissible. This is in line with the criterion in Article 361(3) Sv stating that in case the handling of the claim will cause a disproportionate burden, hindering the criminal trial (geen onevenredige belasting), the court must declare the claim inadmissible. This means that the claim will only be considered by the criminal court when the tort claim is not complicated in any way. This qualitative criterion therefore functions as a barrier to the victim to have his claim for damages dealt with by the criminal court. It replaces the earlier requirement that the

${ }^{68}$ The court fee and the cost for legal assistance are not part of the damage caused by the offence (Art. 361(2)(b) Sv). The ruling must mention a separate consideration; the criteria being similar to those used in civil proceedings (Arts. 237-245 Rv.)

${ }^{69}$ Claimants will always have to pay a certain amount of the cost, however, there is a minimum of 196 Euros for single persons with an annual income of maximum 18,000 Euros and families, or single parent-families, with a maximum income of 25,200 Euros. Those who have an annual income above 25,600 (singles) or 36,100 (other categories) are not entitled to aided legal assistance. If the claim is awarded, however, the cost will be assigned to the tortfeasor.

70 Note the Dutch do not have plea-bargaining; the scheme of adding ad informandum gevoegde feiten is just another example of Dutch pragmatism. Such additional offences do not fall within the full scheme of truthfinding. 
claim must be of a 'simple nature', which criterion was introduced with the Terwee Act in 1995 in order to restrict the complexity of civil claims. ${ }^{71}$ In practice, the new criterion has not changed the evaluation of the complexity of the claims by the courts. Notwithstanding the legislature's wish to extend the range of the adhesion procedure, the courts still interpret the admissibility-criterion rather strictly. ${ }^{72}$

The 'ten minute-rule' is not a legal criterion, but was introduced by the judiciary. ${ }^{73}$ In practice, anything out of the ordinary is seen as a complicating factor so only the run of the mill tort claims are settled in criminal court, that is, for instance, where that there is sufficient evidence that the defendant caused the requested amount of damages. ${ }^{74}$ A hypothetical example of how the criminal court will probably apply the criterion of the disproportionate burden, hindering the criminal trial might help. Consider a victim of aggravated assault who files a tort claim for damages consisting of property damage (ruined clothes), pure economic loss consisting of the inability to work for a couple of years (loss of income) and non-pecuniary damages for his pain and suffering. The district court will probably award the property damage and a fixed amount of money as partial compensation for the non-pecuniary loss and will declare the remaining part of the claim for non-pecuniary damage inadmissible as well as the claim for pure economic loss. Of course, the criminal court can also declare the injured party's claim unfounded in case the victim did not provide enough proof for the claim (see further Section 5 below.).

There is another complication with the adhesion procedure. If the civil claim is ruled admissible but it is ultimately is dismissed, the avenue of the civil law is barred since there has been a substantive judicial review. This would be a particular risk for the claimant if the reduced time and perhaps less extensive experience and knowledge of the civil law made a criminal court less likely to uphold a civil claim. In any case, in order to preserve the avenue of the civil law, the criminal courts are instructed to prefer a ruling of inadmissibility instead of unfounded, leaving it to the plaintiff to file a civil suit. However, in practice, a substantive cohort of the

71 See Section 3.D as well as Section 6.

72 J. Claassens, 'Het slachtoffer in het strafproces' (2012) Strafblad 251; Ten Brinke et.al., 'Het nieuwe ontvankelijkheidscriterium in de praktijk'.

73 Landelijk Overleg Voorzitters Strafsecties, Aanbevelingen civiele vordering en schadevergoedingsmaatregel, October 2011, www.rechtspraak.nl/procedures/landelijke-regelingen/ sector-strafrecht/documents/wet-terwee.pdf (last accessed 28 July 2014).

74 J. Candido et al., Slachtoffer en de Rechtspraak (Deventer: Lovs, 2013), para. 4.2.2. 
crime victims whose claim was (partially or wholly) ruled inadmissible by the criminal courts do not seek recourse by the civil court.

Recently, it has been suggested that there is a need to improve this civil procedure. One target for reform has been a parallel route to claims, the so-called kantonprocedure (Article $117 \mathrm{Rv}$ ). ${ }^{75}$ This is a more informal and faster form of civil justice, as opposed to the 'fully dressed' civil procedure. In particular, there is no obligation to pay court fees and to be represented by a barrister as both obligations are felt to deter claimants from seeking civil recourse. Moreover, since July 2011 the cantonal judge is competent to rule upon claims to a maximum of 25,000 Euros. Research, however, shows that victims still focus on the adhesion procedure. ${ }^{76}$ Thus, the reforms to date have not achieved their purpose.

\section{Clarification of the claim}

After having dealt with the facts mentioned in the indictment, and the personal circumstances of the defendant, the criminal court deals with the civil claim. The claimant, or his legal representative, is given the floor to clarify the claim. Since the claim cannot unduly burden the criminal trial, the clarification by the claimant can only be modest and is time restricted (see further Section 5). Moreover, Article 334(1) Sv denies the claimant the right to call upon witnesses or experts to clarify his claim. Next, in his closing speech, the public prosecutor will include an opinion regarding the claim. Finally, the judge will address the defendant, or in case he is not present, his authorised defence counsel, ${ }^{77}$ to hear the defence's arguments as regards the claim and to learn whether the defendant is willing and able to (fully or partially) pay compensation and has the means to satisfy any compensation order made in case the claim is awarded. Next, the defence is entitled to bring forward their arguments, particularly on quantum and proof of harm. Although the claimant is entitled to have the final comment at the end (Art. 334(3) Sv), this opportunity is seldom used.

75 Parliamentary Papers 2013-14, 33 552, no. 7 (Victim Policy).

76 Schrama and Geurts, Civiel schadeverhaal door slachtoffers na strafbare feiten; Hebly et al., 'Crime Victims' Experiences with Seeking Compensation: A Qualitative Exploration'; R. S. B. Kool, M. R. Hebly et al., Schadeverhaal na strafbaar feit via de kantonrechter (Den Haag: BJu, 2014).

77 Note according to the Dutch rules of criminal procedure, the defendant is not obliged to be present at the trial. In order for the trial to qualify as an adversarial procedure in which defence counsel is able to provide for full defence on his clients' behalf if the client himself is not present, the defence counsel needs to be authorised by the defendant (Art. 279 Sv). 


\section{Ruling by the court}

For minor cases, handled by a single judge, the oral verdict will follow immediately after the hearing. In the more complicated criminal cases, the written verdict must be presented within a two-week term. Where the court rules that a criminal act has been committed, it can also then rule on the tort law aspects of the behaviour in question. The court uses civil law to determine the question of tort damages, although as noted above (Section 3.B), many of the substantive components of the crime are similar to those of tort. Thus the criminal court rules as it were a civil court and applies the rules of tort law. The ruling will be recorded in the verdict as: (in whole or in part) inadmissible, (in whole or part) unfounded or founded. The ruling of unfounded will be given when the victim did not provide sufficient proof of his claim and did not clarify his claim adequately at the trial. That can for instance be the case when, in the hypothetical example mentioned in Section 4.C.2 above, the victim did not provide information about the price of the ruined clothes. Some criminal courts expect a receipt of the purchase of the clothes to be submitted, others accept an overview of pricing of similar clothes. But when there is nothing available about the price of the clothes, the victim's claim will be declared unfounded.

The ruling of the criminal court serves as compelling evidence in any ensuing civil proceedings (Art. $161 \mathrm{Rv}$ ) so potential civil claimants not part of the criminal proceedings usually wait for them to be complete (see further Section 5). The claimant is also entitled to a free copy of the ruling (Art. $554 \mathrm{Rv}$ ).

\section{Appeal}

As the aim of the legal procedure is to provide for redress, the legislature has granted the claimant a right of appeal against the amount of damages awarded but he can only join the prosecutor or defendant's appeals, not bring an autonomous appeal of his own. Where there is such an appeal already in motion, the claimant's appeal will be dealt with by the criminal court again, again acting as a civil court for that purpose. If the Public Prosecution Service nor the defendant appeals, the claimant must appeal to the civil court of second instance. He is, however, only allowed to appeal if the claim exceeds the amount of 1,750 Euros (Article $602 \mathrm{Rv}){ }^{78}$ Note a claim for compensation cannot be brought for the first time before the

78 The rules of the Dutch BW are applied, requiring summons, court fees and legal representation; in practice this opportunity is seldom used. 
Court of Appeal, nor can the claim made be altered (Article 421(3) and (4) Sv). Where claim was partially granted, however, the claimant can appeal for the part that has been rejected. Note also that an appeal in the criminal case defers the verdict of the criminal court of first instance, thus the compensation awarded by this court is not enforceable until the appeal has been determined.

\section{Concurrent claims and additional support}

A wrongdoer's activity may constitute tort and crime, giving way to both a civil and criminal procedure. As the claimant may bring a claim before the civil court (Article 6:162 BW) and the Public Prosecution Service simultaneously may start a criminal prosecution, rulings with regard to the substantive components of tort and crime can run in parallel (in the context of distinct procedures; see Section 4.A.2). Although there is no specific provision for civil courts similar to Article $14 \mathrm{~Sv}$ (whereby the criminal court may adjourn the trial in order to await the outcome of the civil procedure), ${ }^{79}$ a civil judge may choose to suspend the civil claim. This possibility is rationalised in three related ways: first, the civil procedure is slower anyway, so why not take advantage of the faster criminal determination for assistance; second, a suspension makes sense, since a conviction is compelling evidence in civil cases (Article $161 \mathrm{Rv}$ ); and third, it promotes effective management of the court's case load. In practice therefore, concurrent trials and judgments seldom happen.

Nevertheless, there is room for manoeuvre, reflecting the Dutch preference for pragmatic solutions particularly where it might benefit victims. Indeed, the legislature, as well as the Hoge Raad, is prepared to remove legal barriers to the victim's swift compensation, giving rise to rather complicated, yet practical, legal constructions. In particular, a victim can change the route seeking compensation until the point at which that route has concluded with a substantive ruling. This means that if a civil claim has begun, until it has been concluded the victim can still bring a claim before the criminal court, if within the criminal court's time limits. If the criminal court subsequently rules the claim to be partially awarded, the victim must withdraw the other parts of the claim brought and take them to a civil court. If, vice versa, the civil court has partially awarded the claim, the criminal court's sentence will read inadmissible for this part

79 Hoge Raad 23 June 1953, NJ 1954, 116 (the court is not obliged to adjourn the criminal trial in case of disputes with regard to a civil law issue); Hoge Raad 17 February 1957, NJ 1959, 356 (the criminal court is competent to rule on the dispute). 
due to a lack of recognised legal interest to compensated. Next, where the victim can deliver proof that the defendant has not yet satisfied the order made against him by the civil court, the criminal court can - but is not obliged to - award a compensation order for the unsettled part, thus enabling the claimant to profit from the enforcement service of the Central Fine Collection Agency (Centraal Justitieel Incassobureau (CJIB); Art. $361 \mathrm{~Sv}){ }^{80}$ In addition, if the victim was awarded compensation by a criminal court in a sentence which was then appealed, the whole sentence is suspended during the appeal and thus the compensation is unenforceable. If the claimant, for practical reasons, meanwhile seeks recourse by the civil court, his claim will be admissible for there has not been a final substantive ruling. ${ }^{81}$ Finally, where the claimant has brought a claim before the criminal court in the context of an adhesion procedure, he can, request compensation in advance in a civil procedure. Valid reasons for requesting this advance include, for example, attempting to prevent further harm/costs stemming from the original wrong done. These rather complicated legal constructions reflect the autonomous nature of the ruling by the civil courts and the criminal courts.

\section{Remedies: the compensation order and substitute detention}

The criminal court's jurisdiction to hear a civil claim necessitates remedies beyond those available to a criminal trial alone. First, and most importantly, one remedy that a criminal court can impose once there is liability to pay damages to the victim of the crime according to the rules of tort law is the compensation order, the order to pay compensation to the state for the benefit of the victim of the crime (schadevergoedingsmaatregel; Art. 36f Sr). Criminal courts have a discretionary power to impose the compensation order; the legislature did not wanted to oblige the courts to impose the order. However, the criminal courts typically do impose one when the victim's tort claim in the adhesion procedure is awarded by the criminal court. This practice stems from a binding recommendation of the chairs of the criminal sections of the courts, an organ of the Board for the Judiciary. By doing so the courts want to serve the rationale of

${ }^{80}$ Hoge Raad 26 April 2011, NJ 2011, 205; Hoge Raad 19 February 2010, NJ 2010, 131; also: A. H. Sas, 'Strafrecht voor civilisten deel II: over de gewijzigde Wet schadefonds geweldsmisdrijven en nog enkele opmerkingen over schadeverhaal via het strafproces' (2012) Tijdschrift voor Vergoeding Personenschade 58.

81 E.g., District Court Arnhem 16 September 2009, LJN BK0509. 
the Terwee Act: to improve the position of victims of crime as well as to unify the application of the adhesion procedure of Article $51 \mathrm{f} \mathrm{Sv}$ nationwide. Thus the criminal courts went one step further than the legislature because it was acknowledged that the compensation order is in pursuit of the execution of the civil claim, awarded in the adhesion procedure. ${ }^{82}$ The imposition of a compensation order provides an executorial title to be executed by the Public Prosecution Service, on behalf of the victim (Article 572(1) Sv). In practice the CJIB (the Collective Debt Collection Agency) performs the enforcement on behalf of the victim. Since compensation orders represent a criminal sanction, the enforcement can be furthered by the use of police and judicial powers. Most remarkably, substitute detention (discussed below), can be used to force the convicted person to pay. Although the CJIB works closely together with the Public Prosecution Service, both are autonomous organisations in the service of the Department of Security and Justice.

The compensation order, being of a penal nature, can be made of the court's own motion, that is, even without the victim requesting it. ${ }^{83} \mathrm{How}-$ ever, this seldom happens because it may not be clear whether the victim will appreciate receiving compensation from the perpetrator and, more practically, if the victim is not present or consulted in advance, necessary evidence about the harm suffered will be missing. ${ }^{84}$ In addition, a compensation order can theoretically be awarded by the criminal court to support the enforcement of a claim already awarded by the civil court. Clearly, the victim having initiated a civil procedure, s/he is in pursuit of compensation. By awarding a compensation order, the criminal court grants the claimant the benefit of the executorial services of the CJIB. Such awards are rare, particularly due to the fact that criminal proceedings are mostly faster than civil proceedings and offer with the adhesion procedure a much cheaper and less formalistic way to file the tort claim. Nonetheless, the possibility is there, once again showing the pragmatic approach of nature of the Dutch legal system and the strong wish to provide for victim compensation.

The compensation order is strengthened by related orders, such as protective seizure: to prevent the defendant from embezzling his assets in

${ }^{82}$ Landelijk Overleg Voorzitters Strafsecties, Aanbevelingen civiele vordering en schadevergoedingsmaatregel, October 2011, 34-6, www.rechtspraak.nl/procedures/landelijkeregelingen/sector-strafrecht/documents/wet-terwee.pdf (last accessed November 2014).

${ }^{83}$ Ibid., 36. ${ }^{84}$ Candido et al., Slachtoffer en de Rechtspraak, 169. 
an attempt to escape having to pay the victim compensation, the police and the public prosecutor can seize assets in advance (Art. 94a(3) Sv). ${ }^{85}$

If there are multiple defendants, the court will impose the compensation order on each of them individually for the full amount of compensation awarded (the so-called hoofdelijkheid). On the one hand, Dutch criminal law uses distinct categories of perpetrators (Arts. 47 and 48 Sr):

(1) the individual who commits an offence by himself (plegen);

(2) those who (more or less) act together, co-participation (medeplegen);

(3) those who merely assist the main perpetrator, complicity (medeplichtigheid);

(4) those who provoke someone else to commit the offence by making promises, using force or other means, incitement (uitlokking); and

(5) those who use another individual instrumentally to commit the crime, while that other individual is not criminally liable, acting via an intermediary (doen plegen).

These distinctions, however, are not relevant for the liability with regard to the obligation to compensate the damages caused, for the liability is based on the civil law. Again, the rationale lies in the legislature's wish to relieve the victim of the burden and risks of enforcement. Thus the risk of insolvency of the perpetrator(s) should not bother the victim: if one of them has not provided for full compensation, the victim - due to the executive efforts of the CJIB - can recover from one or more of the other convicted defendants.

As noted above, a remarkable fact of Dutch law is that a compensation order is accompanied by an order for substitute custody in default: the perpetrator must serve detention if he does not satisfy the compensation (Art. 36(8)f Sr). The obligation to impose substitute custody has met with criticism. In particular, it is particularly harsh since serving substitute detention does not dissolve the civil law obligation to satisfy the compensation ordered; the claimant still holds an executive title against the perpetrator. Indeed, substitute detention merely results in the dissolution of the enforcement by the CJIB and the Public Prosecutor's Service. Once the substitute detention has been fully executed, the victim is left to seek compensation via the civil route, by making use of a bailiff (Art. 554(2) Sv).

85 Staatsblad 2013, 278. See E. Gijselaar and S. Meyer, 'Conservatoir beslag ten behoeve van het slachtoffer’ (2014) 3 Delikt \& Delinkwent 180. 
Finally, a second remedy is that the criminal court can instruct the return of stolen property (Article $116 \mathrm{~Sv}$ ). Such instructions are generally given where the property was seized by the police (Article 95 and $96 \mathrm{~Sv}$ ) in the course of an investigation. As well as serving several aims, for example for the purpose of evidence, or public safety (e.g., possessing a weapon for which the defendant has no permit), seizure can also serve to return property (e.g. stolen goods) to those who it belonged to. In fact, the return of such property is not actually part of the adhesion procedure since the court will do so without a claim being formally made. ${ }^{86}$ Nonetheless, the investigation of who might be entitled to property will tend to also reveal who might have suffered loss and therefore wish to bring an adhesion claim. Indeed, bringing a claim before the criminal court, might further an instruction to return the goods as it reveals the identity of the party entitled.

\section{Advance compensation}

In order to guarantee the victim of sexual offences and/or violent offences receive the compensation quickly, the legislature recently granted victims (or in case of death, his/her relatives) who were awarded compensation by the criminal court the right to receive compensation in advance, to be provided by the state (Art. 36(f)(7) Sr). Such an advance will only be granted if the perpetrator is unable to pay within an eight-month period. Moreover, the damages awarded must relate to crimes in the category of sexual offences and/or violent crimes which are summed up in an Order in Council. ${ }^{87}$ In 2016, however, this offence limitation will be lifted, with the effect that advance compensation will be available for all offences, but will be capped at 5,000 Euros. While the state, who pays this advance up front, will have a right of recourse against the convicted person, it is foreseeable that a substantive cohort of perpetrators will be unable to pay the compensation. ${ }^{88}$ Again, this illustrates how highly the victim's interest in receiving compensation is valued within modern Dutch legal policy.

86 There is, however, one condition: the defendant must renunciate the seized goods.

87 Art. 1(2) Uitvoeringsbesluit voorschot schadevergoedingsmaatregel, Staatsblad 2010, 311. The crimes are Art. 141, 239-253, 273f, 287-291, 300-303, 312 and 317 Sr.

88 There are, however, also plans to introduce a so-called slachtoffer-tax, implying perpetrators to be obliged to pay a certain amount of money to cover for the cost with regard to State compensation; Parliamentary Papers 2012-2013, 33 552, no. 5. 


\section{Why are tort and crime procedurally connected}

Why then are tort and crime procedurally connected in the Dutch discourse? First one has to bear in mind that the Dutch legislature traditionally has been receptive to the victim's wish for compensation. Indeed, as early as the end of the nineteenth century, at the time of the introduction of the first national code of criminal procedure, an adhesion procedure was introduced, albeit limited to small claims only (see Section 3.D). While this was criticised as being contrary to the parallel desire to ban the victim from criminal proceedings, ${ }^{89}$ however, compassion overcame resentment.

Political intentions, however, changed over time. The right to prosecute still lies in the hand of the Public Prosecution Service, and although the possibilities to claim compensation have been widened, it still is qualified as a subordinated item that may not unduly burden the criminal proceedings. On the other hand, a clear shift in the victim's position in the Netherlands can be seen in other mechanisms, and developments are still pending. For instance, to date, the victim has only been acknowledged as a stakeholder, having participatory rights. This implies, however, not an acknowledgment as a 'party', on equal footing with the defendant. Nevertheless, in view of current proposals to introduce an advisory right for victims, indicating them to be entitled to advise the judge on the issue of evidence and sentencing, one can observe a nascent but important shift within the Dutch paradigm..$^{90}$ Victim's compensation, indeed, is highly valued within the present political discourse, however, so are the (overall inquisitorial) features of Dutch criminal procedural law and the dogmatic distinction between tort and crime. While trying to strike a balance but also pursuing an adequate response to victims' needs, ${ }^{91}$ the legislature is

${ }^{89}$ For an historical overview: R. S. B. Kool, 'Uit de schaduw van het strafrecht' (1999) 9 Justitiële Verkenningen, 60-73.

90 To date, the Dutch are on the cusp of an important change, which will have major dogmatic consequences: a draft bill has been introduced to award the victim an advisory right related to the evaluation of the evidence and the imposition of sentencing Parliamentary Papers 2014/15, 33176, no. 1-3. For a review: R. S. B. Kool, 'Alles naar wens? Observaties naar aanleiding van het conceptwetsvoorstel ter aanvulling van het spreekrecht voor slachtoffers en nabestaanden in het strafproces' (2014) 3 Tijdschrift voor Herstelrecht, 9 and R. S. B. Kool and G. Verhage, 'The (Political) Pursuit of Victim Voice: (Comparative) Observations on the Dutch Draft on the Adviesrecht' [2014] Utrecht LR 86.

91 To provide for 'an adequate response' has become the slogan used by the legislature with regard to victim's policy. The slogan was taken from the research project Strafvordering 
apparently willing to opt for convergence between tort law and criminal law, loosening up the dogmatic distinction and introducing pragmatic solutions to further victims' compensation.

This increasing focus on victims' need has not only been a feature of Dutch law. Both within Europe and on a worldwide scale, victims of crime are at the centre of political attention, urging national authorities to provide for an adequate legal procedural framework for compensation. Within the Dutch legal discourse, Book 2, Title IIIA, section 2 Sv, together with some articles mentioned in Title VI, section $2 \mathrm{~Sv}$, provides such a framework. The rights related to the issue of compensation (Title IIIA, section 2, Art. $51 \mathrm{f}-\mathrm{h} \mathrm{Sv}),{ }^{92}$ however, are separated from other procedural rights focused on procedural justice (Title IIIA, section 1, Art. 51a-e Sv). Nevertheless, the latter can also be of benefit to the issue of compensation, for example the right to disclosure and the right to legal assistance (Art. 51b and c Sv). Moreover, the MSJ plans to simplify the civil procedures for awarding compensation. The aim is to lower the hurdles to a successful civil claim after a criminal court has ruled an adhesion claim inadmissible or has partially rejected it, for instance, by removing court fees, or the obligation to be represented by a barrister.

It seems highly likely that this search for an adequate modus to facilitate the victim's interest, especially his need for compensation, will lead to further 'procedural exchanges' between the civil law and the criminal law. Moreover, one can expect the measures to be introduced not to be restricted to the issue of how to further compensation and the relationship between tort and crime. Against the backdrop of the attention for procedural justice further convergence between tort and crime is to be expected, shedding new light on the traditional relevance of procedural differences. ${ }^{93}$ This hybridisation, however, is firstly to be expected regarding sentencing. Already, Article $36 \mathrm{f} \mathrm{Sv}$ provides a clear example. Next, the plan to introduce a new behavioural order can be mentioned (Art. $38 \mathrm{z} \mathrm{Sr}$ ). The intention is to introduce the possibility to impose a measure in order to subject certain convicted persons (mostly sexual and violent offenders) to long-term supervision, behavioural training and/or

2001, which set out the contours of contemporary victim's policy; M. S. Groenhuijsen and N. M. Kwakman, 'Het slachtoffer in het vooronderzoek' in M. S. Groenhuijsen and G. Knigge (eds.), Dwangmiddelen en Rechtsmiddelen (Deventer: Kluwer, 2002), 773971.

92 Note Art. 51h Sv to address mediation. The Public Prosecution Service is obliged to further mediation by instructing the police to investigate whether there is room for mediaition.

93 Kool, '(Crime) Victims' Compensation: the Emergence of Convergence'. 
other restrictions of freedom. ${ }^{94}$ This instrument resembles the Civil Protection Orders, applied in the United Kingdom.

\section{Criminal conviction $=$ civil evidence}

\section{A. Introduction}

As noted above in Section 2, Article $161 \mathrm{Rv}$ establishes that once a criminal court has ruled an act to be a criminal act, in a criminal trial at which the defendant was present, this ruling serves as compelling evidence in any ensuing civil proceedings. This criminal conviction is however not conclusive since Article 151(2) Rv affirms, that it is always allowed for a party in a civil suit to bring counterevidence to rebut the evidence of the opposing party, even if the opposing party has brought forward evidence (in this case, by means of the former criminal conviction) which the judge must in principle rely on. The Civil Code of 1838 already contained a similar provision with Article 1955, so the origins of this doctrine date back to 1838 .

In the Dutch system, such a rule makes sense. Since a criminal act is also considered to be a tort the civil judge who gets a case after it has been through a criminal trial will basically be answering the same questions since the component parts of the tort claim overlap with the elements needed for a criminal conviction. But in real life as in law, there is much more to the evidentiary relationship between tort and crime, as will be seen hereafter. We turn now to look at these rules in more detail, again looking at where, how and why it plays out.

\section{B. Where is the overlap (or the difference)?}

1. Substantive overlap, evidentiary differences

There are several points of 'overlap' between the substantive law with regard to tort and crime. However, the proof of the substantive points of overlap between tort and crime is evaluated by different standards. For instance, the concept of causation shows common ground (since the standard of 'reasonable imputation' is used in both areas of the law, see above at Section 3.D), but a key difference is that stricter standards of proof are applied in criminal cases.

94 Parliamentary Papers 2013-14, 33 815, nos. 1-2. At the time of writing (September 2014), the draft is still pending. 
As for negligence, this is a prerequisite in tort law according to Article 6:162(3) BW, but within criminal law such negligence represents the lowest level of fault: usually more is required (for instance, intent). The different use of these points of departure for both areas of the law can be explained by the need for a restrained use of the criminal law as a tool of last resort. In particular, criminal law implies that prosecution is justified in terms of 'public benefit', whereas the point of entrance for tort law lies in the fair allocation of losses.

As for defences, for instance, self-defence, the Criminal Code provides for general provisions that apply to all offences, and these same defences are recognised and used (as unwritten rules) in tort law. ${ }^{95}$ The standard of proof as regards such defences is, however, in criminal cases lower than usual: the defendant only has to put forward a plausible defence. ${ }^{96}$ This standard seems to resemble the civil standard that will be set out below.

\section{Standards of proof}

What can be gathered from the above is that, although there is some overlap as to the evidential value of criminal convictions (a conviction is to be accepted as proof in civil cases if no rebuttal evidence is forthcoming), the elements of criminal law have a different standard of proof to those of civil law. Let us elaborate somewhat on that thought, starting with tort law (which serves as an example of private law more generally) ${ }^{97}$

The standard of proof in civil cases refers to the extent or degree of certainty or probability that the evidence delivered by the litigants must generate in the mind of the judge when deciding an issue of fact. ${ }^{98}$ If the required degree is reached, the court can say it is convinced of the 'truth' (whatever that may be in a more philosophical sense) of a certain factual proposition and decide the case accordingly. Included in the foregoing description is the notion that in principle, but with exceptions, the courts in the Netherlands, as in other parts of Europe, are free to attach their own weight to different pieces of evidence. Whether they believe an eyewitness

95 See Hartkamp and Sieburgh, Mr. C. Assers Handleiding, nos. $88 \mathrm{ff}$.

96 If such a defence is not accepted, the criminal judge has to put forward a deliberate, written opinion giving the reasons for this choice (Art. 358(3) Sv). For civil cases, this rule is unknown; the usual standard for giving reasons in judgments applies.

97 The following part is taken, with minor adjustments, from: I. Giesen, 'The Burden of Proof and Other Procedural Devices in Tort Law' in H. Koziol and B. S. Steiniger (eds.), European Tort Law 2008 (Springer: Wien, 2009).

98 See P. Murphy, Murphy on Evidence (Oxford University Press, 2007), 101. 
or not, to give one example, is at their discretion. Related to that notion is the starting point that the standard of proof is decided according to the weight that the judge in question decides to give the evidence. It is thus in principle a subjective judgment, one which is objectified however by the obligation for a judge to give reasons for his decision. ${ }^{99}$

As to the degree or extent of evidence required to pass the standard of proof hurdle, it would seem that common law and civil law countries are divided. ${ }^{100}$ In England ${ }^{101}$ proof 'on the balance of probabilities' ('is it more likely than not?') would suffice for a civil claim, while elsewhere the measure to reach for civil claims is put (somewhat) higher, for instance at 'a reasonable degree of certainty' in the Netherlands or 'at a practical degree of probability or certainty that silences doubt without totally excluding it' as it is specified in Germany, which is an even higher standard, laid down in paragraph 286 Zivilprozessordnung (ZPO) and usually described as sehr hoher Warscheinlichkeit (i.e. a very high probability). ${ }^{102}$ And in Austria, to give one more example, the required degree is that of die hohe Warscheinlichkeit (a high probability); this is based on paragraph 272 österreichische Zivilprozessordnung (öZPO) and case law. ${ }^{103}$

It is also noteworthy that in most systems the standard of proof can vary according to the type of case that is being dealt with. In Germany, for instance, the degree of certainty can and sometimes is lowered in certain private law cases when Glaubhaftmachung, or überwiegende Wahrscheinlichkeit, which translates as 'more probable than not', seems to suffice. ${ }^{104}$ In line with that, Dutch courts lower the standard in

99 For details, see I. Giesen, Bewijs en aansprakelijkheid (Den Haag: BJu, 2001), 49 f., at 53-5.

100 See for instance E. L. Sherwin and K. M. A. Clermont, 'A Comparative View of Standards of Proof (2002) AJCL 243. The ALI/Unidroit Principles of Transnational Civil Procedure try to bridge the gap by stating in Principle 21.2: 'Facts are considered proven when the court is reasonably convinced of their truth'. See further on this 'divide' and on this Principle: M. Brinkmann, 'The Synthesis of Common and Civil Law Standard of Proof Formulae in the ALI/Unidroit Principles of Transnational Civil Procedure' (2004) Unif L Rev 875.

101 Chapter 2.2.E.4. See also Murphy, Murphy on Evidence, 107. See also (in German) Chr. Schröder, Das Beweisrecht im englischen Zivilverfahren (Munich: Peter Lang Publishing Group, 2007), $222 \mathrm{ff}$.

102 See Giesen, Bewijs en aansprakelijkheid, 50 and 55; H. -J. Musielak, Grundkurs ZPO (Munich: C.H. Beck Verlag, 2007), 281; BGH, 17 February 1970, Entscheidungen des Bundesgerichtshofs in Zivilsachen (BGHZ) 53, 245, 256 (Anastasia-Urteil). For Belgium, a degree of redelijke zekerheid suffices, see B. Allemeersch, Taakverdeling in het burgerlijk proces (Cambridge: Intersentia, 2007), 466.

103 See the discussion (and further references) in C. Bumberger, Zum Kausalitätsbeweis im Haftpflichtrecht (Linz: Trauner Verlag, 2003), 45 ff., 49 and 182; OGH, 9 July 2002, Juristische Blätter (JBl) 2003, 249 f.; OGH, 17 November 2004, JBl 2005, 464.

104 Musielak, Grundkurs ZPO, 283. 
so-called kort geding procedures. These are very fast preliminary proceedings, issued at short notice, before a single judge, based mainly on oral arguments, in cases where a speedy decision is needed due to the nature of what is at stake. There, the standard is lowered to aannemelijkheid: 'is it probable?' ${ }^{105}$

The principle aim of the standard of proof is to have a certain measure to decide whether the burden of proof has been discharged and applied equally to all litigants in the same sorts of cases. In order to perform that function, the degree of evidence required as such could also be easily varied. A variation in the degree required would be feasible if in a given situation demanding that more evidence be supplied would be unjustified. For possible reasons why demanding more evidence might be unjustified, one refers to the general justifications for a court to accept a reversal of the burden of proof. For example, one party has in fact caused the evidentiary problems of the opposing party, or there is a substantive justification such as the need for the law to protect employees against employers to a certain extent. ${ }^{106}$

The standard of proof, however determined and set, will be of influence on the burden of proof; this in turn will affect how much work the concept of proof does in deciding cases. If a court is convinced of the existence of a certain fact, the required evidence apparently has been brought forward, allowing the judge to decide the matter accordingly. The risks associated with the burden of proof are then no longer at stake: it would be impossible to have a so-called non liquet situation, the situation in which the fact that needed to be proven has not been proven according to the standard of proof applicable. ${ }^{107}$ From this it follows that if the required standard were to be lowered, the degree of evidence necessary to reach the standard would also be lower, making it less likely that the burden of proof will be decisive for that case at hand. Lowering the standard, as happens in kort geding proceedings, noted above, results in fewer cases being decided on the burden of proof. ${ }^{108}$ The Civil Code, Article 6:97 BW, also provides, in some cases, for the claimant to estimate the amount of damage suffered, and use a lower standard of proof. ${ }^{109}$

105 See Giesen, Bewijs en aansprakelijkheid, $56 \mathrm{ff}$.

106 For elaboration, see ibid., 475 and $477 \mathrm{ff}$.

107 See for instance G. Baumgärtel, Beweislastpraxis im Privatrecht (Berlin: Heymanns, 1996), no. $377 \mathrm{ff}$.

108 C. Bumberger, Zum Kausalitätsbeweis im Haftpflichtrecht (Linz: Trauner Verlag, 2003), 42.

109 Compare for Germany paragraph 287 ZPO. The same deviation from the regular standard applies, according to paragraph $252 \mathrm{BGB}$, for the determination of lost profits. 
Within criminal law, ${ }^{110}$ as already alluded to, the standard of proof is that the facts supporting a conviction must be 'legally and convincingly proven'. 'Legally' denotes here that proof must be delivered by means of the categories of evidence mentioned within Articles 339-44a Sv. As for the further evaluation of the evidence so presented, the Dutch criminal law also uses the so-called 'free system': assuming the minimum rule has been fulfilled (normally, that there is more than one) it depends on the personal, professional opinion of the judge whether he is convinced of the perpetrators guilt or not.

Turning to the application in practice of these provisions, for some years now, criminal law requires a reasoned and written explication in the verdict of the judge's evaluation of the facts in the indictment that needed to be proven (Article 359(2) Sv). ${ }^{111}$ Although the law nowadays specifies that an acquittal needs to be reasoned as well (Arts. 359(2) and 352(2) $\mathrm{Sv})$ courts are a bit reluctant in following this instruction except for high profile media-cases.

In practice, a judge will confine himself to making referrals to the specific pieces of evidence on which the verdict is based (police reports, witness statements, confiscated objects and so on), so in essence the standard of proof poses not too much of a burden. If the defence attorney has raised clear arguments that are rejected, the judge is obliged to explicitly provide for an answer to those objections. ${ }^{12}$

\section{Compensatory mechanisms}

When considering these rules on the standard of proof, one must be aware however that there might be other mechanisms to compensate for a difficult procedural position of one of the parties. For instance, at least in civil cases, it might be that the burden of proof can be shifted between parties, a so-called reversal of the burden of proof. Other private law mechanisms that could be used in just about any case where evidentiary problems arise include: presumptions of fact, including res ipsa loquitur; the duty to provide additional information and, as alluded to already, a lowering of the standard of proof. ${ }^{113}$

110 See on the following G. J. M. Corstens and M. J. Borgers, Het Nederlands strafprocesrecht (Deventer: Kluwer, 2011), 675-7.

111 These are the so-called Promis verdicts.

112 However, if the rejection of such an argument follows logically from the facts mentioned in the verdict, such an explicit answer is not required.

113 See Giesen, 'The Burden of Proof and Other Procedural Devices in Tort Law' in Koziol and Steiniger (eds.), European Tort Law 2008 (Springer: Wien, 2009). 
The rule in criminal cases is that the prosecutor has to deliver evidence to substantiate that the facts are 'legally and convincingly proven'. There's one exception: the procedure in cases of ontneming van wederrechtelijk verkregen voordeel (what might be called the dispossession of unlawfully obtained advantages). This is in many cases a separate procedure, following the main criminal procedure, aiming at getting a legal title to confiscate finances/possessions that are assumingly related to the criminal activities that the individual has been convicted for in the main procedure. The standard of proof differs here since it suffices to make such a correlation 'assumingly present', to use an ugly translation of the Dutch terminology. As for the application of exclusionary defences, such as self-defence, in criminal law, it is up to the defence to provide arguments for what might be called the 'assumingly presence' of such a defence. This is another example of lowering the standard of proof, the threshold for proving an element of the criminal case.

\section{Means and production of evidence}

When it comes to the means and production of evidence, the criminal and civil law rules diverge considerably, which is of great significance for legal practice. In criminal cases the Dutch system provides for a strict regime of evidence, at least as to the categories of evidence. This is exemplified by the use of the 'minimum rule' mentioned above: a person may not be convicted on the basis of a sole piece of evidence. There is however, one rather important exception to this rule and that is that a report, under oath, of a police-officer that is based upon the direct observation of the offence, can and will be accepted. This exception, and some less common ones, means that one must not have too high expectations of this minimum rule; in practice, the amount of evidence in the majority of the cases is in fact rather poor.

Experts or witnesses may present evidence, orally in court or in written form (if indicated, followed by further explication in court) and their statements may be used by the judge. Although the defendant has a right to present contrary expert evidence, he has to pay for the costs thereof himself, which is a significant impediment. Furthermore, to guarantee the use of qualified forensic experts only, the legislature has recently introduced an official register of forensic experts who may be called upon in criminal proceedings. That said, in some fields of forensic evidence the state acts as a monopolist, for example, in the field of DNA-evidence. ${ }^{114}$

114 However, initiatives are employed to bring more competition to this field. 
The defendant is not called upon as a witness; although he is questioned in court, he is cautioned and not obliged to testify. But, it must be stressed, adverse inferences can be drawn by the judge if the defendant decides to remain silent.

In regular tort cases, dealt with in civil courts, the claimant has to bring forward a plausible claim, providing sufficient evidence of the tortious act, the fault, the damage itself, as well as the causes of the damage which have to relate sufficiently to an act or omission by the respondent. If this body of proof supports a plausible claim - the 'minimum rule' from criminal law does not exist in civil law - the defendant needs to refute this by providing counter-evidence. The judge in a civil procedure will receive and then weigh the evidence but does not collect it himself. That is for the parties: they may in principle bring forward any piece or form of evidence they see fit (see Art. 152(1) Rv), such as witnesses, video and audio tapes, a party appointed expert and so on. In this regard the system is adversarial in nature.

As regards witnesses, there are some restrictions on their admissibility but these are rather trivial; an offer to bring in a witness testimony must in principle be awarded if the witness may have something to say about the factual position that needs to be proven. Even though the judge himself can order evidentiary measures (hearing witnesses, for instance) ex officio, this hardly ever happens. What does happen to some extent, however, is that the judge orders an expert opinion by a court appointed expert (see Arts. $194 \mathrm{Rv}$ et seq.), usually because the party appointed experts seem to disagree.

\section{Powers of investigation and disclosure}

Of course, the gathering and presenting of evidence goes hand in hand with the questions as to the powers of investigation and the rules for disclosure for those involved in civil and criminal proceedings. When it comes to the powers of investigation, the Dutch civil courts take a rather passive stance towards the gathering of (evidence to prove) facts. A civil judge takes the case and the evidence as presented to him by the parties, even though he has ex officio powers. However, if required, the court can request further information from the parties, as set out in, for instance, Article $22 \mathrm{Rv}$ : the disclosure of this information then rests on the parties themselves. It is also for the parties to name the proposed witnesses who are then obliged to testify. Forsaking this duty to testify may lead to the witness being brought to the court by force and even placed in custody, 
if needed. ${ }^{115}$ Given these rules, the outcome of a civil case will not always equal 'the truth.' ${ }^{116}$

Be that as it may, the Dutch consider that criminal courts more actively search for the truth, the so-called 'substantive truth' (that is, what has in fact happened), as opposite to the 'procedural truth' (what seems to have happened given the formal restrictions of the proceedings as regards the fact-finding and gathering and admissibility of evidence) which features in more adversarial systems. Nevertheless, because the Public Prosecution Service is in charge of the investigative stage, and also of the composition of the dossier and the indictment, judges are rather reluctant to carry out any additional investigation. However, if the court is of the opinion that there is a need for more information, the trial will be suspended in order to carry out an additional investigation, for example, additional interrogations or forensic investigation. An order to complete this additional investigation can be given to an investigative-judge, but one of the judges on the bench of the case at hand may also be appointed.

It will not be surprising to learn that the rules for disclosure, as well as the compellability of witnesses, differ from those in a civil court setting. This is the case because in a criminal, more inquisitorial setting, the Public Prosecution Service is in charge of the criminal investigations, and thus also in charge of granting disclosure and compelling witnesses. Recently, the Public Prosecution Service has been given full charge of the investigative phase, but before the case is tried in court an investigative judge evaluates whether there is a need for further evidence. This provides the defence with an opportunity to put forward requests regarding disclosure or the hearing of witnesses. Once the decision to prosecute has been taken, the defence is entitled to full disclosure subject only to exceptions such as where disclosure would be a threat to public security.

\section{Intermediate conclusion}

Due to the application of stricter rules and standards of proof in criminal cases the substantive overlap in rules and terminology is in practice of limited importance. If a component of a crime or tort is substantively the same but in need of more convincing proof, there will be a relevant difference between a civil tort case and a criminal case.

115 See Arts. 172 and 173 Rv. Taking a witness into custody is also known as 'an imprisonment for debt'.

116 On this topic, see particularly R. de Bock, Tussen waarheid en onzekerheid: over het vaststellen van feiten in de civiele procedure (Deventer: Kluwer, 2011). 


\section{How are tort and crime related in evidentiary matters?}

How can the relationship between tort and crime be classified and characterised, especially in terms of evidence? Are there cross-influences? Are these influences direct or indirect? As already noted in Section 3.D the relation between tort and crime is not analysed in the Netherlands in terms of a 'relationship' or 'hierarchy'.

Needless to say, however, there are, as we have already seen, some intersections between tort and crime. The most evident and direct influence, from the point of view of evidence, is marked by Article $161 \mathrm{Rv}$ as mentioned before. A criminal conviction after a full-blown criminal trial provides the civil judge with all the evidence he needs to conclude that the act in question was tortious. But that is about all that can be said here, because that same civil judge will need to assess on his own as based on the evidence brought before him by the parties whether key tortious requirements have been met: that the act in question was imputable to the defendant (by way of guilt or risk allocation, see Art. 6:162(3) BW; $;^{117}$ to be sure, in practice there is hardly any evidentiary hurdle as regards this imputation requirement ${ }^{118}$ ), that there was a legally relevant loss suffered and what the amount of damages might be for that loss, whether the unlawful act was a condicio sine qua non of the damage, and so on.

To the extent that there is some movement from one side of tort and crime to the other in respect of evidence, it is clear that it this movement is one-sided only. Criminally tested evidence has high standing in civil court, but that is not the case the other way around. If a civil judge has already ruled an act unlawful that does not mean that a criminal judge must then conclude that a criminal act was committed also. So, where the civil system shows some porosity or permeability, the criminal system shows none.

\section{Why are tort and crime so connected?}

As suggested in Section 2, the Dutch seem to have found - at least for the time being - an efficient way of handling the overlap between tort and crime that they recognise their system naturally generates (because of

117 Quoted in Section 2.B. This is at least the case in theory, in practice there is hardly any evidentiary hurdle as regards the imputation requirement.

118 To elaborate: if a criminal act that requires some element of intent (a form of dolus or culpa) has been established by the criminal court, the civil judge will also rule that the tortious act was imputable to the defendant in the civil sense. The law however, does not expressly oblige the judge to do so. 
Art. 6:162 (2) BW). This way of handling the system turns particularly on reasons of unity and coherence. The evidentiary overlap and legislative permission to build on a criminal conviction as evidence in a civil trial is only a logical consequence thereof. And indeed, shows why the question 'why not let the civil judge use the evidence gathered and already judicially tested (to a high standard) and considered in criminal court if such evidence is indeed present' is truly rhetorical.

\section{Tort and crime over time}

It is interesting to note that - from a certain perspective - Dutch law on the interplay between tort and crime has been in place for decades without a lot of significant changes to the system. As much can be seen from the long history of some form of adhesion procedure set out in Section 3.D. The only truly interesting shift has been the growing amount of recognition and attention that the victims of crimes have received and the ensuing improvement of their position within the criminal trial.

This stability is due, perhaps, to the fact that the use of tort law within a criminal procedure - this is where in the Netherlands the actual interplay takes place - usually involves the relatively simple cases. Anything complex, from a tort law perspective, is thrown out of the criminal court immediately. The substantive components of torts and crimes have not generated much interest. A theft is always a tort, and physical abuse also constitutes both a crime and a tort. The substantive private law rules that the victims of crime would need to rely on - and thus, that politicians would be interested in - was therefore never in need of any change. Only the procedural aspect, relating specifically to the rules of criminal procedure, i.e. the place and role a victim of a crime might be given in criminal proceedings, was and is deemed politically interesting enough to gain and keep momentum. Since the 1970s the victim's position within the criminal procedure has become subject to continuous political debate. From then on, and in line with international developments, Dutch policymakers have shown themselves to be highly receptive to victims' needs. Subsequent coalition cabinets, being driven by electoral considerations and responding to the social call for legal protection of certain groups or interests provoked by the so-called 'risk-society' we (seem to) live in, have prioritised victims' issues, urging for both legal and policy changes. These changes, however, have been of a somewhat incoherent nature. Legal initiatives by Members of Parliament, failing to take into account the doctrine and system of private law and criminal law, set the political agenda, giving way to incident-based law reforms. As a result of all these 
factors, Dutch law has adopted a pragmatic viewpoint, especially on the procedural possibilities offered to victims of crime to obtain compensation and/or recognition (see Section 4).

In 2009, however, a coherent catalogue of victims' rights was introduced, including, amongst others, the traditional right to compensation. This legislative revision, however, did not end the quest for victims' rights. On the contrary, it provided a boost for further developments. The current Dutch Government even made the establishment of a crime victims' policy one of its objectives. This crime victims' policy aims at improving the position and the rights of victims of crime before, during and after the criminal trial. ${ }^{119}$ One of its five objectives is to simplify and enhance the possibilities for victims of crime to actually receive financial compensation and other forms of redress. Or, to put it differently, according to the Dutch Government, in policy language: 'The victim's damage is to be paid by the perpetrator.' 120 This shows that policymakers seek to find ways to serve the victim's interest with regard to compensation and redress. Indeed, victims having high expectations of the legal possibilities, the policymakers are eager to live up to these expectations in order to prevent disappointment and related risk of legitimacy. Relying on the criminal justice system to do them justice, in particular with regard to compensation, victims of crime find their way to criminal courts with their tort claim and use the adhesion procedure. However, these victims are often proven disappointed: due to the subsidiary nature of the claim for compensation a substantial number of claims are ruled to be (partially) inadmissible (see Section 4.C). This concerns particularly the more complicated tort claims, due to the criterion of unduly overburdening the criminal trial, and this is often related to serious crimes. Victims can of course subsequently start a civil procedure, however, this seldom happens. ${ }^{121}$ Being aware of the risk of secondary victimisation and related loss of legitimacy, Dutch policymakers are in continuous pursuit of ways to adapt the legal procedures in order to serve the interest of victims' compensation. These

119 Parliamentary Papers 2012-13, 33 410, no. 15, 25.

120 See Parliamentary Papers 2012-13, 33 552, no. 2, 6-7 respectively Parliamentary Papers 2012-13, 33 410, no. 15, 25.

121 Very few cases are filed in Dutch civil courts in which damages are sought on the basis of an act which is also a crime. Even the civil parts of those criminal cases that are not dealt with in criminal court in the adhesion procedure, hardly ever go to civil court. See for facts and figures Schrama and Geurts, Civiel schadeverhaal door slachtoffers na strafbare feiten and Hebly et al., 'Crime Victims' Experiences with Seeking Compensation: A Qualitative Exploration', (2014) 3 Utrecht L Rev $27 \mathrm{ff}$. 
changes, however, have not (yet) destabilised the traditional distinction between tort and crime. Furthermore, these politics appear to have had a side-effect, academics already observing 'victim-fatigue'. ${ }^{122}$

The changes already accomplished, however, represent pragmatic solutions instead of a fundamental reassessment of the system, dogma and doctrine of the Dutch (civil and criminal) law. The criminal courts tend to apply the rules of tort law less strictly and, in case the claim is too complex to be handled, are willing to award 'compensation in advance', meaning a small part of the sum to be awarded, thus showing compassion with the victim. ${ }^{123}$ Moreover, being aware of the complexity of the civil route, the legislature is considering the introduction of a so-called 'folding mechanism', implying an automatic transfer of the victim's claim to the civil court. ${ }^{124}$ These developments seem to be, however, rather more symbolic than of a fundamental nature. However, no option should be discarded out of hand because we do not know what the future holds in terms of convergence with regard to tort and crime. ${ }^{125}$ We expect that the political attention with regard to victims' rights, specifically the issue of compensation, will not cease. Bearing in mind the populist tune in today's Dutch victims' policy, 'pragmatism and efficiency' could serve as a breeding ground for more fundamental legal changes, giving way to a significant convergence of tort law and criminal law. Suggestions have been made to strengthen the enforcement function of tort law, in order to prevent tortious wrongs in the first place, rather than providing retrospective redress. ${ }^{126}$ These suggestions imply that tort law is to become instrumentalised, serving - in its own way - the public interest. Moreover,

122 M. S. Groenhuijsen, 'The Development of International Policy in Relation to Victims of Crime' (2014) 20(3) IRV 31.

123 The legal basis of such an advance being unclear, one can hear criticism; e.g. M. J. Heemstede and A. H. Sas, "Rechter maakt van voorschotregeling een wassen neus", www.NJB.nl/ blog/rechter-maakt-van-voorschotregeling-een-wassen-neus.11111.lynkx (last accessed 28 July 2014).

124 Note this proposal initially comes from the Board for the Judiciary. The latter is an independent organ, established in 2002 responsible for the management and business of and allocation of budget to the courts. It also provides advice to the Ministry of Security and Justice on bills and policy issues which have implications for the administration of justice. It aims at improving the quality of the (legally independent) judiciary. See: www. rechtspraak.nl/english/Pages/default.aspx (last accessed November 2014).

125 Kool, '(Crime) Victims' Compensation: the Emergence of Convergence'.

126 W. H. van Boom, Efficacious Enforcement in Contract and Tort (The Hague: BJu, 2006); I. Giesen, 'Handhaving in, via door en met het privaatrecht: waar staan we nu?' in E. F. D. Engelhard, I. Giesen, C.B.P. Mahé and M.Y. Schaub (eds.), Handhaving van en door het privaatrecht (The Hague: BJu, 2009), 310-312. 
a recent (28 May 2014) draft bill sent to consultation from the Ministry of Security and Justice seeks to introduce compensation for bereavement damages in tort law, as well as in criminal law, although with a system of tariffs. ${ }^{127}$ It also seeks to offer certain family members and next of kin of the victim killed as a consequence of a crime the possibility of claiming bereavement damages in the adhesion procedure in criminal proceedings. ${ }^{128}$ However, we do not suggest that these developments and proposals will result in a 'melt down' of the traditional distinction between tort and crime. Nevertheless, we do observe clear signs of convergence present within the Dutch discourse.

\section{Conclusion}

The Dutch are often considered to be more pragmatic than philosophical. Efficiency, or at least, searching for as much efficiency as possible, seems to go well with that. That might be the starting point for an explanation for the way the Dutch legal system handles the tort/crime connection. Referring back to what was stated earlier in this chapter, we can only conclude that when it comes to the relationship between tort and crime the Dutch legal system seems to be in search of - and has found, we thinka rather efficient way of handling the overlap between tort and crime. Let one court do all the work instead of bringing in more judges dealing with parts of the bigger problem. This manner of operation is consistent with legal standards and values like 'unity of the legal system' and 'coherence', but such 'big' words are seldom used in the Netherlands in this respect. This might suggest that the homogeneity of the legal system so reached is only a side-effect and not a sought-after purpose. It has only been by looking outside the Netherlands that we came to use such terminology and such a principled approach to something that works so profoundly pragmatically in everyday life in the Netherlands.

127 About a system of tariffs, see for instance J. Candido and S. D. Lindenbergh, 'Strafrechter en smartengeld: de civiele vordering in het strafproces al aanjager van een rechtsontwikkeling' (2014) 21 NTBR 173; (from a comparative perspective) I. Giesen, 'Normering van schadevergoeding in Engeland: een les voor Nederland?' (2001) NJB 120.

128 See www.rijksoverheid.nl/nieuws/2014/05/28/ruimere-schadevergoeding-voorslachtoffers-en-hun-naaste-omgeving.html (last accessed November 2014). 